OPEN ACCESS

Edited by:

Irun R. Cohen,

Weizmann Institute of Science, Israel

Reviewed by:

Anne Schumacher,

Otto von Guericke University

Magdeburg, Germany

Baojun Zhang,

X'an Jiaotong University, China

${ }^{*}$ Correspondence:

Joanne Kwak-Kim

joanne.kwakkim@rosalindfranklin.edu

Specialty section:

This article was submitted to Immunological Tolerance

and Regulation,

a section of the journal

Frontiers in Immunology

Received: 02 April 2020

Accepted: 27 July 2020

Published: 18 August 2020

Citation:

Wang W, Sung N,

Gilman-Sachs A and Kwak-Kim J

(2020) T Helper (Th) Cell Profiles

in Pregnancy and Recurrent

Pregnancy Losses:

Th1/Th2/Th9/Th17/Th22/Tfh Cells.

Front. Immunol. 11:2025.

doi: 10.3389/fimmu.2020.02025

\section{T Helper (Th) Cell Profiles in Pregnancy and Recurrent Pregnancy Losses: Th1/Th2/Th9/Th17/Th22/Tfh Cells}

\author{
Wenjuan Wang ${ }^{1,2}$, Nayoung Sung ${ }^{1}$, Alice Gilman-Sachs ${ }^{3,4}$ and Joanne Kwak-Kim ${ }^{1,3 *}$ \\ ${ }^{1}$ Reproductive Medicine and Immunology, Obstetrics and Gynecology, Department of Clinical Sciences, Chicago Medical \\ School, Rosalind Franklin University of Medicine and Science, North Chicago, IL, United States, ${ }^{2}$ Reproductive Medicine \\ Center, The Affiliated Yantai Yuhuangding Hospital of Qingdao University, Yantai, China, ${ }^{3}$ Center for Cancer Cell Biology, \\ Immunology and Infection, Chicago Medical School, Rosalind Franklin University of Medicine and Science, North Chicago, \\ IL, United States, ${ }^{4}$ Clinical Immunology Laboratory, Center for Cancer Cell Biology, Immunology and Infection, Chicago \\ Medical School, Rosalind Franklin University of Medicine and Science, North Chicago, IL, United States
}

During pregnancy, various immune effectors and molecules participating in the immunemicroenvironment establish specific maternal tolerance toward the semi-allogeneic fetus. Activated maternal immune effectors by the trophoblast antigens, such as T helper (Th), T cytotoxic (Tc), T regulatory (Treg), and B cells, are involved in the regulation of adaptive immunity. Recognition of active signal through the $T$ cell receptors stimulate the differentiation of naive $\mathrm{CD}^{+}{ }^{+} \mathrm{CD} 4^{+} \mathrm{T}$ cells into specific $\mathrm{T}$ cell subsets, such as Th1, Th2, Th9, Th17, Th22, and follicular Th cells (Tfh). Each of these subsets has a significant and distinct role in human pregnancy. Th1 immunity, characterized by immune-inflammatory responses, becomes dominant during the peri-implantation period, and the "controlled" Th1 immunity benefits the invading trophoblasts rather than harm. Quickly after the placental implantation, the early inflammatory Th1 immunity is shifted to the Th2 antiinflammatory immune responses. The predominant Th2 immunity, which overrules the Th1 immunity at the placental implantation site, protects a fetus by balancing Th1 immunity and accommodate fetal and placental development. Moreover, Treg and Th9 cells regulate local inflammatory immune responses, potentially detrimental to the fetus. Th17 cells induce protective immunity against extracellular microbes during pregnancy. However, excessive Th17 immunity may induce uncontrolled neutrophil infiltration at the maternal-fetal interface. Other Th cell subsets such as Tfh cells, also contribute to pregnancy by setting up favorable humoral immunity during pregnancy. However, dysregulation of Th cell immunity during pregnancy may result in obstetrical complications, such as recurrent pregnancy losses (RPL) and preeclampsia (PE). With this review, we intend to deliver a comprehensive overview of $\mathrm{CD}^{+}{ }^{+}$Th cell subsets, including Th1, Th2, Th9, Th17, Th22, and Th cells, in human pregnancy by reviewing their roles in normal and pathological pregnancies.

Keywords: Th1 cell, Th2 cells, Th9 cells, Th17 cells, Th22 cells, pregnancy, recurrent pregnancy loss 


\section{INTRODUCTION}

T helper (Th) dichotomy of Th1/Th2 immune responses was proposed by Mosmann and colleagues (1) in 1986. This concept was adapted to explain maternal tolerance toward fetal alloantigen in 1993 by Wegmann et al. (2). Domination of Th2 immunity, which overrules Th1 immunity during pregnancy, was hypothesized to protect the fetoplacental unit from the attack of maternal Th1 cells (2). Indeed, obstetrical complications, for instance, recurrent pregnancy losses (RPL) and preeclampsia $(\mathrm{PE})$, have been documented to be associated with predominant Th1 immunity (3-5), although RPL was also documented with shifted Th2 immunity $(6,7)$. The paradigm of Th1 and Th2 dichotomy was then incorporated with a concept of regulatory T cell (Treg) immunity, which was first described in 1979 by Chaouat and Voisin (8), to explain maternal-fetal tolerance further. In 2010, the Th1/Th2 paradigm for maternal immune tolerance was expanded to the Th1/Th2/Th17 and Treg cell paradigm (9). This paradigm was able to better answer the conundrum of fetal tolerance during pregnancy comprehensively by adopting not only Th17 immunity but Treg immunity, which confer expanded tolerance to encompass semi-allogeneic fetal antigens in addition to tolerance to self-antigen and extended-self commensal antigens (10).

Recent advances in immunology have revealed the existence of additional Th cell subsets at the maternal-fetal junction, of which roles beyond the contribution of Th1, Th2, and Th17 cells (11), including Th9 (12), Th22 (12-14), and follicular Th (Tfh) cells (15). In this review, we recapitulate the reported functions of various Th cells at the maternal-fetal junction and document how aberrant Th immunity is associated with RPL.

\section{PLACENTAL HLA ANTIGENS REGULATE T CELL ACTIVATION AT MATERNAL-FETAL JUNCTION}

Villous trophoblasts, including cytotrophoblasts and syncytiotrophoblasts, and syncytiotrophoblast microparticles (STBM) lack any human leukocyte antigen (HLA) expression and do not present major histocompatibility complex (MHC) class I and II transcriptional activators, like class II transactivator and NOD-like receptor family CARD domain containing 5 (NLRC5) (16). $\mathrm{CD}^{+}{ }^{+} \mathrm{CD} 4^{+} \mathrm{Th}$ and $\mathrm{CD}^{+}{ }^{+} \mathrm{CD} 8^{+} \mathrm{T}$ cytotoxic (Tc) cells interplay with HLA class II and I antigens, respectively. Once activated, Th cells release various cytokines that are essential for the activation of Tc cells, isotype switching of B cells, and bactericidal activity of phagocytes, including macrophages. Therefore, lack of HLA class I and II antigens may protect villous trophoblast cells from $\mathrm{T}$ cell alloreactivity in normal pregnancy (17). However, in pathological pregnancies, such as PE, HLA-DR, HLA class II antigen, was detected in a significant proportion of syncytiotrophoblast and syncytiotrophoblastderived extracellular vesicles (STEVs) that are either the fetal or maternal origin, possibly acquired by trogocytosis. Therefore, the activation of inflammatory Th cells in patients with PE may partly be explained by the pathological expression of HLA-DR in syncytiotrophoblast and STEV (18).
Contrary to villous trophoblast, HLA C, classical MHC class I molecule, HLA E, F, and G (19), non-classical MHC class I molecules, and MHC transcriptional activators, such as NLR family pyrin domain containing 2 (NLRP2), are expressed in extravillous cytotrophoblast (EVT) (16). NLRP2, highly expressed in EVT, is also expressed by the JEG3 human choriocarcinoma cells, which is the EVT cell line, but not in decidual stromal cells. Although NLRP2 is an MHC transcriptional activator, it has been reported to suppress constitutive HLA-C expression in JEG3 cells and TNF- $\alpha$-induced NF- $\mathrm{B}$ activation (16). Therefore, NLR family members may link innate immunity to adaptive immunity by participating in the regulation of MHC expression during inflammation. Since NLRP2 suppresses pro-inflammatory immune responses, it may contribute to avoid undesirable anti-fetal responses (16).

Maternal Tc lymphocytes recognize paternal HLA-C and minor histocompatibility antigens (mHAg), such as HY, on trophoblasts, which has been reported in numerous people and during a healthy pregnancy. Indeed, HLA-C histoincompatibility at the maternal-fetal junction has been documented to induce a tolerogenic microenvironment $(20,21) . \mathrm{CD}^{+}$Tc cells can indirectly recognize fetal antigen and undertake clonal deletion, yet, cytotoxic effector function is not primed; consequently, antigen-specific fetal demise cannot be induced even with artificial activation of these cells (22). Therefore, maternal $\mathrm{T}$ cells, particularly Tc cells, target EVT since it expresses paternal HLA-C, but its level of expression may determine how the maternal alloreactivity by Tc cells is molded. Tight transcriptional regulation of HLA-C expression allows balancing between the induction of tolerance and alloimmunity at the maternal-fetal junction (23). In mice, alloimmune recognition of maternal $\mathrm{T}$ cells was exclusively through maternal antigenpresenting cells (APCs), which uptake and process the fetal antigens. Contrarily, in the human placenta, $\mathrm{T}$ cell recognition of allogeneic fetus was severely restricted, since antigen presentation is constrained by low levels of antigen uptake, and gradual presentation of fetal antigens to $\mathrm{T}$ cells, via maternal APCs, such as dendritic cells (DCs), allowing immune tolerance (22, 24). Once activated, $\mathrm{CD} 4^{+}$Th cells participate in maternal immune responses, particularly by regulating adaptive immunity (22). When decidual DCs were specifically exhausted, the poor decidualization of human endometrium was noticed with inadequate endometrial vascularity, leading to impaired implantation of blastocysts (25). Therefore, not only the characteristics of placental HLA antigen expression but its presentation via APC may participate in $\mathrm{T}$ cell regulation at the maternal-fetal interface and inducing maternal tolerance to fetal antigens.

\section{Th1 IMMUNITY FOR CONTROLLED INFLAMMATION DURING IMPLANTATION}

A propensity to Th1 over Th2 immune response is generally recognized during the peri-implantation period by the presence of immune-inflammatory changes. The controlled Th1 shift actually benefits the invading trophoblasts rather than damaging 
them (26). During early pregnancy, the inflammatory priming of peripheral blood mononuclear cells (PBMCs) is established (26). Circulating STBM stimulates the various inflammatory cytokine production, including IL-12, TNF- $\alpha$ and low level of IL-18, from monocytes (27) and contribute to establishing a mild systemic inflammation. Consequently, low IL-18 level induces limited production of IFN- $\gamma$, by which an overall type 2 immunity is maintained during pregnancy $(26,28)$. PBMCs can be recruited to decidua. Specifically, chemokine receptor expressions (especially CCR molecules) on $\mathrm{CD}^{+}{ }^{+} \mathrm{T}$ cells determine their trafficking patterns, including the target tissue, timing, and signals to receive (29). Once $\mathrm{T}$ cells are recruited to the uterine lining, these cells are induced to display unique phenotypic properties by the micromilieu of the maternal-fetal interface (30, 31). Quickly after the placental implantation, the Th2 shift is seemingly noticeable, which is critical for the maintenance and development of normal fetus and placenta (32), and as well as suppression of Th1 immunity at the maternal-fetal junction $(2,9,13,33)$.

Th1 cells secrete various cytokines, typically interleukin (IL)2 , TNF- $\alpha$, and IFN- $\gamma$, which participate in immune surveillance and prevent excessive trophoblast invasion (34). TNF- $\alpha$ has been reported to protect the fetoplacental unit (34) and have a regulatory role in trophoblast invasion by altering trophoblast cell adhesion to laminin and inhibiting trophoblast cell mobility in vitro (35). Contrarily, TNF- $\alpha$ has been associated with the immunopathology of various obstetrical complications. TNF- $\alpha$ elevates trophoblast-derived plasminogen activator inhibitor-1 (PAI-1) levels and decreases the invasive capacity of trophoblasts $(36,37)$. TNF- $\alpha$ produced by monocytes from preeclamptic patients induces apoptosis of human trophoblast cells (38) and inhibits JEG-3 (trophoblast-like cell) incorporation into maternal endothelial cell complex by inhibiting MMP-2 and aborting integrin switch from $\alpha 6 \beta 4$ to $\alpha 1 \beta 1$. TNF- $\alpha$ activates endothelial cells $(38,39)$, and activated monolayer endothelial cells repel JAR cell incorporation (40). TNF- $\alpha$ induces matrix metalloproteinases-9 (MMP-9) but not MMP-2 expression in the decidua of preeclamptic women and disrupts the decidual extracellular matrix to interfere with normal stepwise EVT invasion $(41,42)$. Therefore, a delicate balance of TNF- $\alpha$ at the placentation site is critical for a successful pregnancy.

IFN- $\gamma$ mRNA expression has been reported in implantation sites of healthy pregnant women and the murine model $(43,44)$. IFN- $\gamma$ has an essential role in vascular remodeling during the peri-implantation period $(45,46)$. In mice, the local IFN $-\gamma$ levels of the pregnant uterus reached a peak on gestation day (GD) 10 , which was significantly higher than the baseline IFN- $\gamma$ level (47). IFN- $\gamma$ increases EVT apoptosis and/or decreases protease activity, in turn, regulating EVT invasion. Hence, IFN- $\gamma$ has a critical role in early placentation and the trophoblast invasion process. Contrary to these physiological roles, IFN- $\gamma$ has a potent pro-inflammatory role. It increases HLA class I and II antigen and toll-like receptor (TLR) expressions in innate immune cells, promotes isotype commutation, induces chemokine secretion, activates macrophages, and increases phagocytosis (48). In a porcine model, increased IFNG gene expression at the placental attachment site was associated with early arresting conceptus on gestation day (GD) 20, while the site of a late arresting conceptus (GD 50) had increased TNF mRNA expression (49), suggesting a presence of specific localization mechanism of cytokine expression regulated by the fetal placental unit and phase-specific cytokine responses during pregnancy (50).

The potential immunopathological effects of type 1 cytokines on pregnancy have been demonstrated in animal studies and human pregnancies. Lipopolysaccharide (LPS) injection to 14.5 gd pregnant Wistar rats induced maternal inflammation and subsequent fetal losses in a dose-dependent manner. Alive fetuses had significant growth restriction as well. Administration of IL-10, which has immunoregulatory properties, and TNF- $\alpha$ receptor blocker etanercept, prevented LPS-induced pregnancy losses (51). In addition, either the direct introduction of Th1type cytokines in large amounts, such as IL- 2 or IFN- $\gamma$ or indirect increase of Th1-type cytokines by activation of TLR induced fetal resorption in mice (52). In human pregnancy, increased percentages of IFN- $\gamma^{+} /$Th1 and IFN- $\gamma^{+} / \mathrm{Tc1}$ cells were reported in the decidua of women who miscarried a genetically normal fetus $(N=19)$ as compared with those of induced abortions $(n=15)$ (53). In addition, decidual T cells from women with miscarriage expressed increased IL2 and IFN- $\gamma$, and decreased IL-4 and IL-10 as compared with those of normal pregnancy, and Th1 cytokine production was positively correlated with CD86 and CD28 expression (54). In women with RPL, Th1 bias was present both locally (decidua) and systemically at the time of abortion $(N=24)$ as compared to those at the time of normal delivery $(N=39)$ (55). In a study of women who experienced RPL $(N=26)$, IFN- $\gamma^{+} / \mathrm{IL}-4^{+}, \mathrm{TNF}-\alpha^{+} / \mathrm{IL}-4^{+}$, and TNF- $\alpha^{+} / \mathrm{IL}-10^{+}$producing Th1/Th2 cell ratios were significantly higher in the peripheral blood than those of healthy fertile controls (56). Additionally, women with RPL had increased $\mathrm{T}$ cell activation with systemic Th1 dominance compared to normal fertile women (57). When shifted Th1 immunity was regulated with intravenous immunoglobulin G (IVIg), TNF blockers, or T cell activation inhibitors, such as etanercept, adalimumab, or tacrolimus, pregnancy outcome was significantly improved in women with RPL (58-62). Therefore, time and cytokine-specific regulation of Th1 immunity during pregnancy is critical for a successful pregnancy outcome.

Underlying autoimmune diseases may contribute to Th1 immunity during implantation and pregnancy. In autoimmune diseases, including Hashimoto's thyroiditis (63), systemic lupus erythematosus (64), antiphospholipid antibody syndrome (65), the initial stage of Sjogren's syndrome (66) and scleroderma (67), shifted Th1 immunity or Th17 upregulation have been reported, and RPL has been often associated with these conditions (6870). For instance, in women with Hashimoto's thyroiditis, Th1 cells actively involve the inflammatory lymphocyte infiltration of the exocrine glands and epithelia and cause subsequent thyroiditis, glandular damages, and apoptosis of thyroid cells (71). Moreover, Th1 cells are also recruited to the endometrium, decidua, and placenta, and activate NK cells, resulting in spontaneous abortion (72). Therefore, Th1 immunity, a shared underlying immunopathology, induces RPL in women with autoimmune diseases. 


\section{Th2 IMMUNITY AND MATERNAL-FETAL TOLERANCE}

Th2 immune dominance has been documented in both normal pregnancy $(1,73)$ and RPL $(7,9,74)$. During pregnancy, uterine DCs actively participate in the naive $\mathrm{T}$ cell differentiation into Th2 cells (75). Paternal antigens in trophoblasts activate Th2 cells at the maternal-fetal junction $(3,76,77)$ and Th2 cells infiltrate into the decidua basalis $(78,79)$. Th2 cells, then, induce local Th2 dominance by releasing Th2-type cytokines, which could promote maternal-fetal tolerance. In a rodent study, when Th2 immunity was induced by IL-10 administration to a pregnant mother, pregnancy loss was prevented $(51,80)$. Th2 immunity represses the development of Th1 and Th17 immunities by releasing IL-4 and IL-13, respectively, and promotes allograft tolerance (81). Therefore, IL-10 or another type 2 cytokines may improve pregnancy success (82).

As pregnancy progresses further, maternal immune responses are shifted away from type 2 immunity toward inflammatory and counterregulatory responses. In a study analyzing serum from pregnant women $(n=16)$, IL-1 $\beta$, IL-6, IL-8, IL-12p70, IL13, IL-15, IP-10, and FLT3-ligand levels were increased in relation to gestational weeks while serum IFN $\alpha 2$, IL-1ra, IL-3, IL-9, IL-12p40, and soluble CD40L levels were increased with the advancement of the trimester (83). The re-shifting of Th2 immunity to inflammatory responses may be associated with the preparation of parturition.

Th2 cells may participate in autoantibody production and enhance autoimmunity. The aberrant and sustained expression of IL-4 in vivo prolonged autoreactive B cell survival by suppressing apoptosis. Th2 cytokine, IL-4, was reported to induce autoreactive $\mathrm{B}$ cell activation and thus promotes autoimmunity (84). Therefore, exacerbated Th2 immunity during pregnancy may induce autoimmune diseases or flareup underlying autoimmune conditions. Th2-type autoimmune diseases, such as systemic lupus erythematosus, could get worse (85) when type 2 cytokines were increased during pregnancy. Additionally, increased tolerogenic signals from Th2 cells may induce uncontrolled viral infections. In the fatal ZIKA virusinduced microcephaly, predominant expression of Th2 cytokines was found in meninges, perivascular space, and parenchyma. It was speculated that the active participation of Th2 cells was the immunopathogenic mechanisms of the ZIKA virus (47). Hence, timely and adequate Th2 immunity is important for the immunotolerance and protection of fetus from infection.

\section{INCREASED Tfh CELLS DURING PREGNANCY TO FAVOR HUMORAL IMMUNITY}

Follicular Th cells are characteristically recognized by the master regulator transcription factor, B cell 6 (BCL6), CXCR5, and STAT3 (86). Tfh cells offer cognate assistance to B cells (87). Pregnant women in the third trimester have a higher proportion of peripheral blood Tfh cells (\%) than non-pregnant women, despite co-expressing markers, including programmed death (PD)-1, ICOS, or CXCR3. Furthermore, pregnant women had a significantly higher proportion of CXCR3 ${ }^{+}$Tfh cells (\%) than non-pregnant women, which can secrete IL-6, IL-10, and IL-21, and notably, $\mathrm{PD}-1^{+} / \mathrm{CXCR} 3^{+}$Tfh cells are positively associated with peripheral blood estrogen levels (15). In mice, uterine and placental $\mathrm{CD} 4^{+} \mathrm{T}$ cells express $\mathrm{CD} 4^{+} \mathrm{CXCR}^{h i} \mathrm{PD}-1^{h i}$ and $\mathrm{CD} 4^{+} \mathrm{CXCR}^{h i}{ }^{\text {ICOS }}{ }^{h i}$ phenotypes like Tfh cells, which represent memory and activation status. In the uterus, these cells are abundant and reach a peak at mid-gestation; however, in the placenta, they are increased at late gestation (88). Pregnancy, which accompanies the high estrogen level, has been suggested to positively influence the proportion of Tfh cells specialized in helping B cells, thus, favoring humoral immunity (15) and balancing Th1/Th2 immune responses. Therefore, during pregnancy, a timely and proper accumulation of Tfh cells may assist in the maintenance of a successful pregnancy, while an excessive or lack of accumulation could result in miscarriage (88).

\section{THE ROLE OF Th9 CELLS IN THE PROGRESS OF PARTURITION}

Th9 cells, which are determined by potent production of IL-9, might participate in host-pathogen interaction, antitumor immunity, and immune-mediated diseases, including allergy and autoimmune inflammatory diseases (89). Th9 cells, a subpopulation of Th2 cells, are different from Th2 cells phenotypically and functionally, and subject to PPAR- $\gamma(90)$. TGF- $\beta$ can convert Th2 cells to IL-9 producing cells (91). Furthermore, Th1 or Th17 cell fostering cytokines like IL-1 $\beta$, IL-12, or IL-21, enhance IL-4/TGF- $\beta$-induced $\mathrm{CD} 4^{+} \mathrm{IL}-9^{+} \mathrm{T}$ cell differentiation when $\mathrm{pbCD} 3 / \mathrm{sCD} 28$ stimulation is present (92). Although IL-9 has been historically categorized by type 2 cytokines (93), innate lymphoid cells (ILC) mostly produce IL-9 (94). Th-17 cells produce IL-9 when TGF- $\beta$ is present, and IL-9 participates in the induction of inflammation (95). During pregnancy, peripheral blood IL-9 levels are increased as a function of the trimester, plausibly being resultant of changes in the cellular composition of peripheral blood (83). In a mouse study, IL-9 was reported to present in the non-pregnant uterus. During pregnancy, it remained at a high level in both uterus and placenta, signifying its regulatory role in local inflammatory immune responses which can be a potential threat to the offspring (96). In mice, the decline in decidual Th9 cells together with IL-6 controlled infiltration of $\mathrm{CD} 4^{+} \mathrm{T}$ and $\mathrm{CD} 8^{+}$Treg cells in decidua were involved with progress of parturition (97). Studies for Th9 cells in human pregnancy are limited currently, and a possible role of Th9 cells in parturition should be investigated further.

\section{ABERRANT Th17 IMMUNITY IN PREGNANCY LOSSES}

In peripheral blood of healthy population, Th17 cells are rare among $\mathrm{CD}^{+} \mathrm{T}$ cells $(0.64-1.4 \%)(98,99)$. During all stages of pregnancy, Th17 cell proportions among $\mathrm{CD} 4^{+} \mathrm{T}$ cells were 
reported to be comparable to that of non-pregnant status (99), although another study reported that the pregnant women in the third trimester had a decreased proportion of Th17 cells as compared with non-pregnant women (100). The decidua contains a higher density of Th17 cells than in the peripheral blood (99), and the decidual $\mathrm{IL}-17^{+}$cell count was parallel to the neutrophil count, which suggests that $\mathrm{IL}-17^{+}$cells are intimately involved in neutrophil infiltration (101) and induce protective immunity against extracellular microbes in the uterus. Th17 cells are not only involved with infectious immunity but contribute to human pregnancy. In a study of JEG3 cells, the capacities of progesterone secretion and tissue invasion were increased with IL-17 stimulation (102). Additionally, Th17 cells induce activation of decidual NK ( $\mathrm{dNK}$ ) cells and impair vascular reactivity of uterine arteries (103), leading to embryo resorption (103-105). Excessive Th17 cells have been detected in the decidua and peripheral blood of inevitable abortion (11, 106-110). IL7/IL-7R pathway was reported to up-regulate Th17 immunity while downregulating Treg immunity (111).

Women with unexplained RPL (uRPL) demonstrated an increased proportion (\%) of peripheral blood Th17 cells and related cytokine levels (IL-17A) during the proliferative and secretory phases of the ovulatory cycle than those of normal controls (112). Contrarily, Treg cells and associated cytokines, including IL- 10 and TGF- $\beta 1$, were lower during the proliferative phase in women with uRPL than those of controls. Women with uRPL had a significantly higher Th17/CD4 ${ }^{+}$Treg cell ratios as compared to fertile controls (107), during both proliferative and secretory phases (112). Hence, the balance between Th17/Treg cell immunity may determine pregnancy outcome.

\section{PROMOTION OF TROPHOBLAST SURVIVAL BY Th22 CELLS}

Th22 cells typically produce IL-22 deprived of IL-4, IFN- $\gamma$, and IL-17, and the primary transcription molecule for the Th22 cell differentiation is the aryl hydrocarbon receptor (AHR) (113). IL-22 is involved in various physiologic and pathologic processes, such as immune regulation and allograft rejection, respectively. Hence, IL-22 could potentially harm a pregnancy. At the maternal-fetal junction, the proliferation and viability of trophoblast cells were promoted by IL-22, and apoptosis was significantly reduced by IL-22 (114). IL-22 plays a critical role in protecting trophoblast cells from pathogens (115) and inflammatory immune responses following intrauterine infection (116). Indeed, IL-22 receptors (IL-22R) are expressed on placental villi, and IL-22 from decidual stromal cells and dNK cells bind to the IL-22R1, a subunit of IL-22R (114). IL-22/IL-22R1 pathway might be involved in the promotion of trophoblasts survival and pregnancy maintenance. Women with a history of URPL demonstrate lower IL-22R1 expression compared to women with normal pregnancy (114). Hence, the aberrant activation of IL22/IL-22R1 pathways in placental villi might be linked to the manifestation of spontaneous abortion (114).

ROR $\gamma$ t and T-bet regulate Th22 differentiation positively and negatively, respectively, from naïve Th cells. Conversely,
Th22 cells can be differentiated into Th1 or Th2 cells. Th22 cells demonstrated marked plasticity to produce IFN- $\gamma$ in Th1 promoting conditions in vitro or IFN- $\gamma$-rich inflammatory micromilieu in vivo (117). Th22 cells also demonstrate plasticity to increase IL-13 secretion under the Th2 environment in vitro (117). Decidual CD $4^{+} \mathrm{T}$ cells secreted a more substantial amount of IL-22 than peripheral blood $\mathrm{CD}^{+}{ }^{+} \mathrm{T}$ cells, regardless of normal pregnancy or uRPL (14). Women with uRPL have significantly higher IL-17, IL-21, and IL-22, and significantly lower TGF$\beta$ serum concentrations than those of normal controls (118). However, the contradictory result was also reported in women with URPL with a euploid fetal loss that significantly lower IL22 gene expression in the decidua, and peripheral blood was demonstrated than normal pregnancy (119).

In a successful pregnancy, IL-22 and IL-4 producing $\mathrm{CD} 4{ }^{+}$ $\mathrm{T}$ cells, i.e., Th17/Th2, Th17/Th0, and Th0 subsets, were predominant in the decidua. Contrarily, IL-22 only secreting $\mathrm{CD}^{+}{ }^{+} \mathrm{T}$ cells, i.e., Th17/Th1 subset, were prevalent in the decidua from uRPL (14). In a successful pregnancy, IL-22 ${ }^{+}$Th17/Th2 and Th17/Th0 subsets mainly existed, and GATA-3, ROR-C, AHR, IL-4, IL-17A, and IL-22 mRNA expressions were detected at the implantation site. While mRNA expression of T-bet and IFN- $\gamma$ was detected mainly away from the implantation site. Therefore, IL-22 $2^{+}$Th17/Th2 and Th17/Th0 subsets may have a critical role in embryo implantation (14) (Figure 1). Whether the decidual IL-22 expression is associated with uRPL has not been explored yet.

\section{THE REGULATION OF T HELPER CELLS VIA CO-INHIBITORY RECEPTORS}

$\mathrm{T}$ helper cell activation and differentiation involve genetic control of gene expression by the concerted mechanism of various cytokines, transcription factors, and epigenetic regulators (120). PD-1 (CD279) is a transmembrane inhibitory receptor that ligates with PD-L1 or PD-L2 (121). After stimulation, lymphocytes in various lymphoid organs and tissues with ongoing immunity express PD-1 (122). PD-1/PD-L1 (CD274) axis participates in suppressing autoreactive immune effectors and, consequently, achieve $\mathrm{T}$ cell homeostasis. Accordingly, the PD-1/PD-L1 axis may promote to establish maternal-fetal tolerance $(123,124)$.

PD-1/PD-L1 axis participates in $\mathrm{T}$ cell regulation by suppressing $\mathrm{T}$ cell activation and differentiation, modifying molecular secretion patterns, and inducing cell death and exhaustion of T cells (125-127). The downstream outcome of the PD-1/PD-L1 axis includes the inactivation of PI3K/AKT and Ras-MEK-ERK signaling pathways (128). Anti-PD-1 and anti-PD-L1 block this pathway and induce Tregs suppression. Additionally, these molecules accelerate $\mathrm{T}$ cell proliferation and infiltration, disrupt $\mathrm{T}$ cell equilibrium, and induce proinflammatory micromilieu over tolerance at the implantation site (129). In mice, the PD-1/PD-L1 axis blockade reduced the Treg cells, which result in pregnancy losses by inducing Th1 and Th17 cell differentiation (124, 130, 131). PD1/PD-L1 pathway can also suppress Th22 and Th9 cells through negative 


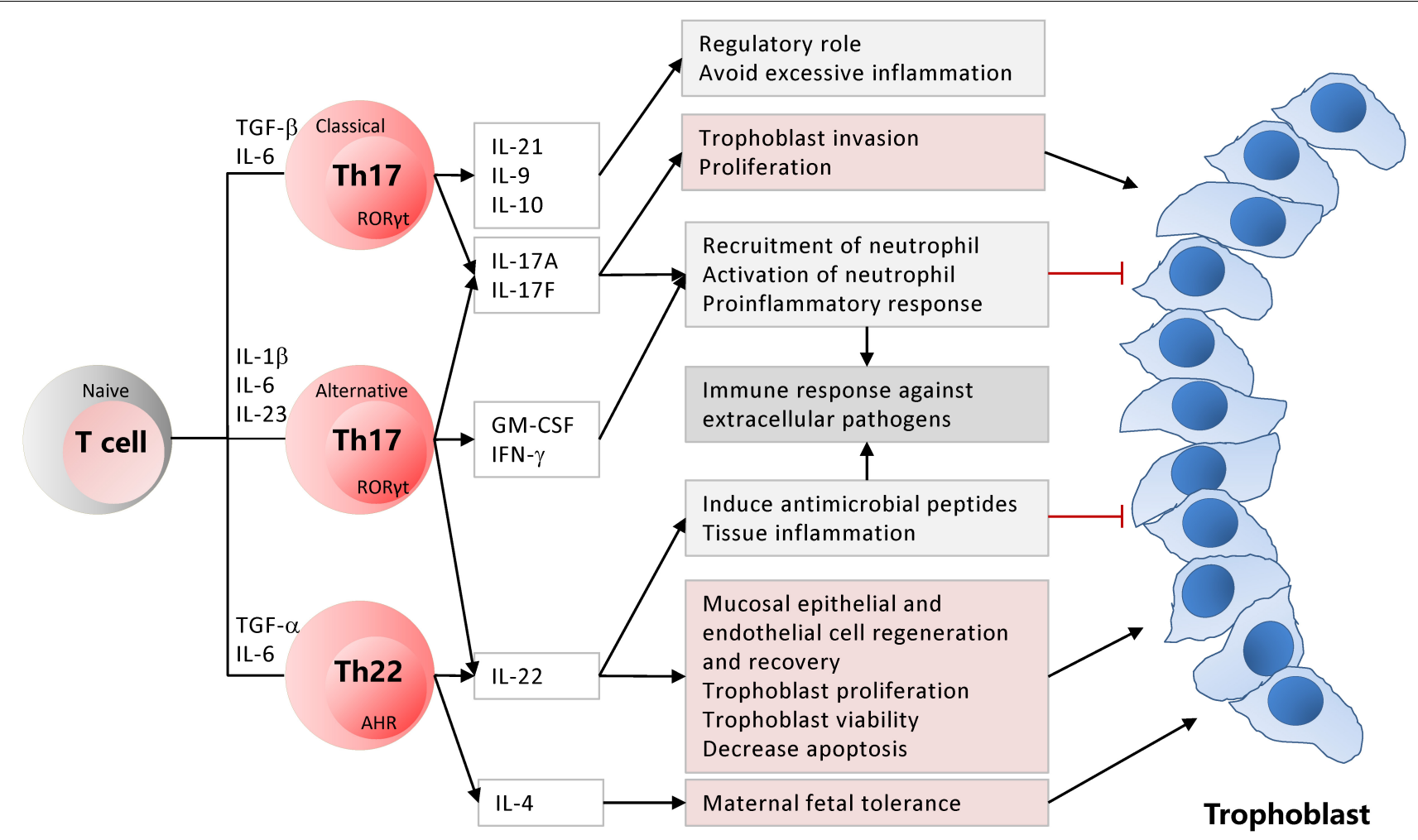

FIGURE 1 | Classical and alternative Th17 and Th22 subsets are differentiated from the naïve CD4 ${ }^{+}$T cells based on differentiation cytokines. Activated Th17 and Th22 cells have critical roles for the maintenance of pregnancy while establishing inflammation and immunity against extracellular pathogens at the maternal-fetal junction.

costimulatory interactions $(132,133)$. In the peripheral blood of women with RPL, CD4 ${ }^{+}$T cells with IFN- $\gamma^{+} / \mathrm{CD} 279^{+}$and TNF$\alpha^{+} / \mathrm{CD} 279^{+}$(PD-1 ${ }^{+}$Th1) and $\mathrm{IL}_{17}{ }^{+} / \mathrm{CD} 279^{+}$(PD-1 ${ }^{+}$Th17) immunophenotypes were significantly lower than those of fertile controls. Women with RPL have significantly lower PD-L1 ${ }^{+}$ Th17 cells, but the similar proportions of PD-L1 ${ }^{+}$Th1 and Treg cells than those of controls (134). Therefore, the propensity to Th1 and Th17 immunity may be associated with RPL by downregulation of $\mathrm{PD}-1$ expression and a sequential disequilibrium among Th17, Th1, and Treg cells (134).

Initially, the $\mathrm{T}$ cell immunoglobulin domain and mucin domain (Tim)-3 was recognized as a Th1-specific receptor present on the cell surface. It transduces an apoptotic signal by engaging Gal-9 and suppresses Th1 immunity (135, 136). Tim-3 and its ligand Gal-9 interaction initiates intracellular calcium influx and suppresses Th1 and Th17 cells (137-139). The Tim-3 blockade induced increased Th1 cytokines at the maternal-fetal junction, and immune tolerance was disrupted (140). Contrarily, Tim-3 can also keep decidual stromal cells from inflammatory damages and TLR-mediated apoptosis by enhancing Th2 immunity at the maternal-fetal junction (141, 142). Thus, in TLR-triggered inflammation during pregnancy, Tim-3 signaling may function as a self-control mechanism (141). The Tim-3 expression was significantly up-regulated in villi and deciduas of pregnant women with RPL compared to normal pregnancies (142-144) as well as in abortion-prone matings in animal models $(145,146)$, representing that the Tim-3 molecule might participate in the immunopathology of RPL (143, 145, 147-149).

Decidual CD4 ${ }^{+} \mathrm{T}$ cells may be controlled by PD- 1 and Tim3 , by which tolerance at the implantation site is promoted. In a normal pregnancy, the decidua contains a higher count of PD$1^{+} /$Tim $-3^{+} \mathrm{CD} 4^{+} \mathrm{T}$ cells than peripheral blood, suggesting their role to support Th2 immunity at the implantation site (135). Contrarily, pregnancy losses may be associated with decreased decidual PD- $1^{+} / \mathrm{Tim}_{-} 3^{+} \mathrm{CD} 4^{+} \mathrm{T}$ cells. However, regardless of pregnancy outcome, Th1 cytokine secretion from these cells was not changed. It indirectly meant that during pregnancy, PD-1 or Tim-3 molecules did not negatively regulate Th1-mediated immunity (149). Instead, the Th2 cytokines from decidual CD $4^{+}$ $\mathrm{T}$ cells were promoted at the implantation site when both PD-1 and Tim-3 pathways were targeted together in a mouse model (149).

\section{PHASE-SPECIFIC Th1/Th2 BALANCE IN A SUCCESSFUL PREGNANCY}

Cytokine production is modified to prepare for the implantation and continuously adapted during pregnancy in many immune cells, including $\mathrm{CD}^{+}{ }^{+}$Th cells $(26,27,50)$. During the window of implantation, IFN- $\gamma$ related gene expressions, such as IL-15, 


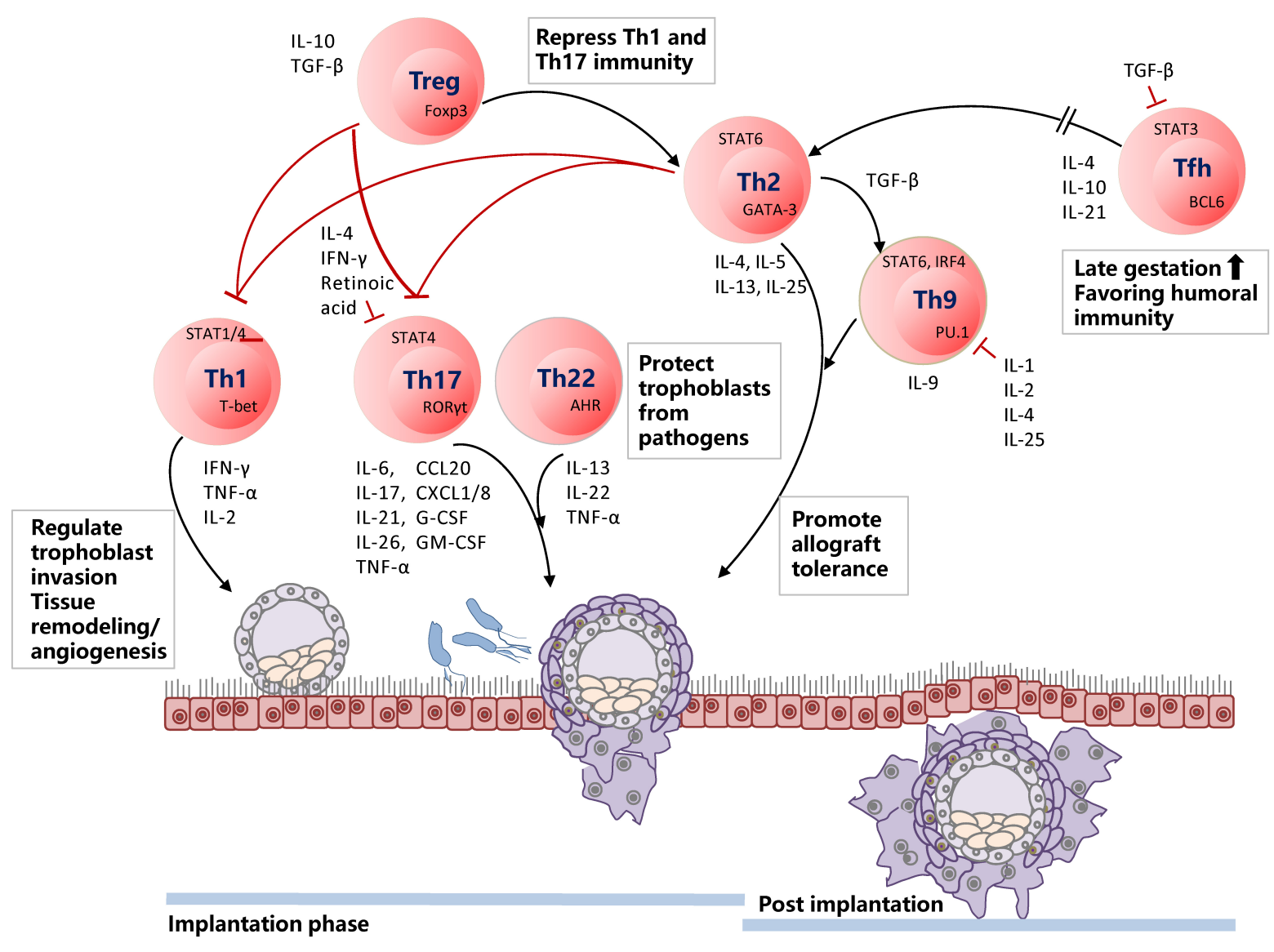

FIGURE 2 | Timely shifting of Th1/Th2 and Treg/Th17 balance is of utmost importance for a successful pregnancy. During the implantation phase, Th1 cells are infiltrated at the decidua and regulate trophoblast invasion by participating in tissue remodeling and angiogenesis. Th17 and Th22 cells are present in the decidua but not enriched. Th17 cells involve in neutrophil infiltration and induction of protective immunity against extracellular microbes in the uterus. Th22 cells also protect trophoblast cells from pathogens and inflammatory immune responses from intrauterine infection. Decreased Th22 cells induce dysfunction of decidual stromal cells and NK cells. Hence, Th22 cells are keenly associated with Th1/Th2 balance. Treg and Th2 cells repress excessive Th1 and Th17 immunity. When the implantation phase is over, Th2 and Th9 cells become dominant and promote allograft tolerance. Tfh cells are usually enriched at late gestation, favoring humoral immunity and, thus, balancing Th1/Th2 immune responses.

in human endometrium are elevated, but not IFNG (150). IL15 , responsible for NK cell proliferation and survival, activates $\mathrm{CD}^{6} 6^{\text {right }} \mathrm{CD} 16^{-}$uNK cells, which play a role in early INF- $\gamma$ expression (151). During implantation, moderate infiltration of decidual Th1 cells is present, but Th2 and Th17 cell densities are not increased (152). Treg and Th2 cells promote allograft tolerance by repressing Th1 and Th17 cells, while Th17 and Th 22 cells protect trophoblasts from pathogens (Figure 2).

Pro-inflammatory Th1-immune response is necessary at the time of implantation to promote tissue remodeling and angiogenesis (153). However, uncontrolled Th1 or Th17 immunity has been related to implantation failures, early pregnancy losses, and repeated implantation failures $(56,108)$. Several factors may affect the Th1 and Th2 balance at the placental implantation site. The local changes in Treg or NKT cells may induce Th1 propensity with up-regulated IFN- $\gamma$ and down-regulated IL-4, and IL-10 expressions, which in sequence, results in RPL $(11,154,155)$. Estrogen and testosterone have been shown to influence cytokine production from $\mathrm{T}$ cells and participate in the pathogenesis of RPL (156). Contrarily, progesterone can actively induce IL- 4 , when its concentration reaches the same level present at the feto-maternal junction $(33,76,157)$. Multiple genes and cytokines expressed in the decidua play an essential role in protecting an invading embryo against excessive Th1 immunity, including TNF weak inducer of apoptosis (TWEAK), its receptor Fn-14, and IL-18, a Th2 promoting cytokine (158).

Once the implantation phase is over, Th1 immune dominance is gradually shifted to Th2 dominance (Figure 2). Decreased number of IL-12 producing decidual DC cells and myeloid DCs induce naïve $\mathrm{CD} 4^{+} \mathrm{T}$ cells to differentiate more into Th2 cells, contributing Th2 cell maintenance in the decidua (46). Moreover, increased Tfh cells during pregnancy favor Th2 immunity, thus balancing Th1/Th2 immunity (15). Activated T cells express galectin-1, which induces down-stream apoptosis (159), repressing Th1 immunity. Galectin-9 (Gal-9), which belongs to the $\beta$-galactoside-binding lectin family, participates in the regulation of Th1/Th2 balance via suppressing the 
production of Th1 cytokine, TNF- $\alpha$, and promoting the secretion of Th2 type cytokine, IL-4 (160). Lastly, during pregnancy, major immunomodulatory molecules from the trophoblast, for example, HLA-G5 (161), favor a shift to Th2 immunity, which may participate in the upkeep of maternal tolerance to fetal antigens (77).

In plasma or serum from normal pregnant women, IL-18 elevation lasts only in the first trimester, IL-12p70 elevation is detected during the first and second trimester, and TNF production is steadily elevated throughout normal pregnancy (26). Once the implantation is over, Th1 immunity is quickly shifted toward the anti-inflammatory Th2 immunity, which dominates until the parturition. NK cells start shifting to Th2 phenotypes during the first trimester by themselves or their products (27), followed by other immune effectors. At the time of parturition, "the second" pro-inflammatory Th1 immunity appears to prepare for the labor and delivery (162, 163). Therefore, the timely shift and adequate balance between Th1 and Th2 immune responses during pregnancy are seemingly critical for a successful pregnancy. Contrarily, failure to achieve a proper balance during pregnancy is associated with obstetrical complications. Increased peripheral blood Th1/Th2 cell ratios have been reported in patients with $\mathrm{RPL}(56,164)$ and preeclampsia (5).

\section{THE RECIPROCAL TRANS-DIFFERENTIATION BETWEEN Th1, Th2, AND Th17 CELLS}

Trans-differentiation of immune effectors makes the more complicated scenario of immune responses at the maternalfetal junction. Th17 precursors can differentiate into the Th17/Th1 subset which secrets both IL-17 and IFN- $\gamma$, and ultimately differentiate into Th1 cells by IL-12 in the microenvironment (165). Whereas memory Th17 cells may differentiate into the Th17/Th2 subset when IL-4 is abundant in the microenvironment, and Th17/Th2 cells typically secrete IL-17 and IL-4 $(166,167)$. The majority of decidual CD4 ${ }^{+} \mathrm{T}$ cells produce both IL-4 and IL-17, so-called Th17/Th2 subset, at the embryo implantation site during successful pregnancy. Contrarily, pro-inflammatory Th17/Th1 cells are prevalent away from the implantation site of an embryo in a successful pregnancy and unexplained RPL (161). In humans, embryo and trophoblast cells produce soluble HLA-G5, which initiates Th17 cell differentiation into Th17/Th2 cells (161). Therefore, decidual micromilieu and HLA products actively control Th cell subsets at the maternal-fetal interface.

\section{THERAPEUTIC APPROACHES TO MODULATE T HELPER CELL RESPONSES}

$\mathrm{T}$ helper cells and their specific subsets could be utilized for diagnostic and therapeutic targets. In women with RPL, RIF, and autoimmune diseases, Th1/Th2 and Th17/Treg cell ratios in peripheral blood are significantly increased as compared to those of fertile controls $(56,71,108)$. Additionally, abortion prone women with successful pregnancy had type 2 cytokine dominance in peripheral blood than abortion prone women with miscarriage (55). Based on these findings, Th cell-related biomarkers, such as Th1/Th2 cell ratios and TNF- $\alpha^{+}$Th1 cell levels, have been translated to clinical medicine, and the diagnostic values of those biomarkers were determined by receiver operating characteristic curve analysis, which was specific to RPL (168). However, the verification of other biomarkers, such as specific cytokines, Th17/Treg ratios, Th17, and Treg levels, has not been made yet in women with RPL or RIF.

Modulation of $\mathrm{T}$ cell immunity in women with RPL and RIF has been a major topic in the field of clinical reproductive immunology and corticosteroids, vitamins, cytotoxic drugs, $\mathrm{T}$ cell activation inhibitors, biologics including cytokine inhibitors, recombinant cytokines, and immunoglobulin $\mathrm{G}$, and cell therapy, have been widely investigated. In an abortion prone mouse model, mesenchymal stem cell (MSC) therapy modulated Th1 immune response to Th2 by increasing the levels of type 2 cytokines, such as IL-4, IL-6, IL-10, and GM-CSF, while decreasing IL-2, IL-12, and IFN- $\gamma$ levels, locally and systemically, and led to maternal tolerance and prevention of fetal resorption (169). In LPS challenged pregnant mice, blockade of TNF- $\alpha$ by a soluble TNFR2-IgG1 Fc fusion protein protected fetal resorption, and placental tissue necrosis was significantly reduced (170). In high-fat-fed diabetic (HFD) NON-cNZO mice, which have higher rates of peri- and post-implantation fetal resorption, tacrolimus and metformin normalized decidual IFN- $\gamma$ and progesterone receptor (PGR) expressions. In addition, these drugs increased immunophilin co-chaperone FKBP52, and colocalization of STATy and PGR, resulting in up-regulated uterine IL-11 and LIF at nidation (171). In abortion prone mice model, blocking of IL-7/IL-7R pathway by IL-7R antagonist significantly down-regulated Th17 immune responses while upregulating Treg immunity in the decidua, and consequently, increased successful pregnancy outcome (111). In laboratory experiments using $\mathrm{T}$ and $\mathrm{NK}$ cell culture, $1,25(\mathrm{OH})_{2} \mathrm{D}_{3}$ was reported to suppress Th1/Th2 cell ratios (TNF- $\alpha / \mathrm{IL}-10$ and IFN$\gamma / \mathrm{IL}-10$ producing $\mathrm{CD}^{+} \mathrm{CD}^{+} \mathrm{T}$ cell ratios) in vitro (172). $1,25(\mathrm{OH})_{2} \mathrm{D}_{3}$, VIPER (a TLR4 specific inhibitory peptide), and BAY11-7082 (an IKK inhibitor), effectively reduced LPS-induced pro-inflammatory cytokine production, including TNF- $\alpha$ and IFN- $\gamma$, through TLR4-NF- $\kappa$ B signaling pathway (173). The effect of $100 \mathrm{nM} 1,25(\mathrm{OH})_{2} \mathrm{D}_{3}$ was the same as those of VIPER and BAY11-7082, suggesting vitamin D can be a potential immune regulator for women with RPL and RIF.

In clinical studies, IVIg, prednisone, TNF-blockers such as etanercept and adalimumab, prednisone, tacrolimus, and vitamin $\mathrm{D}$ have been reported to balance Th1/Th2 and/or Th17/Treg immunity with a varying success rate to prevent RPL (58-60, 174, 175). In a study of women with RPL $(n=44)$, IVIg treatment reduced Th1 cell levels, transcription factor expression, and type 1 cytokine levels, while increasing Th2 cell levels with the substantial decrease in Th1/Th2 cell ratios. Women with IVIg treatment had a significantly higher live birth rate $(87.5 \%, 28$ out 
of 32) when compared to that in controls (41.6\%, 5 out of 12$)$ (58). When TNF inhibitor was added to IVIg treatment in women with RPL and increased Th1/Th2 ratios, the success rate was increased to $71 \%$ from $54 \%$ with IVIg treatment only. However, the success rates between two regimens were not significantly different (62).

Tacrolimus is a $\mathrm{T}$ cell activation inhibitor. In women with RIF and tacrolimus treatment, the Th1/Th2 cell ratio predicted ART outcomes, and the pregnancy outcome was negatively correlated with Th1 cell levels in peripheral blood (60). Hydroxychloroquine, which belongs to the cytotoxic drug, was reported to decrease serum TNF- $\alpha / \mathrm{IL}-10$ ratio during the implantation window of women with RIF with downregulation of T-bet and up-regulation of GATA-3 expression in the endometrium (176). The safety of tacrolimus and hydroxychloroquine during pregnancy has been documented $(177,178)$.

Vitamin D deficiency was prevalent (47.4\%) among women with RPL (172), and vitamin D supplementation significantly increased Treg/Th17 cell ratios when compared to that of controls. The in vitro assay revealed that vitamin D up-regulated mRNA expression of vitamin D receptor and CYP24A1 as well (175). Vitamin D treatment is attractive for RPL and RIF management since it is a vitamin, and the safety for pregnancy is documented with a minimum side effect. There are few other candidate molecules or drugs possibly utilized for women with RPL or RIF. Several signal inhibitors have been utilized for the regulation of Th cells, for example, STA-21 (a dynamic STAT-3 inhibitor) and BJ-3105 (a 6-alkoxypyridin-3-ol analog) to control autoimmune diseases. However, these molecules have not been tested for the prevention of pregnancy losses $(179,180)$.

Criticism of a lack of double-blinded randomized trials has been made regarding therapeutics in reproductive medicine. Due to ethical, legal, and financial constraints of clinical trials for women in reproductive cycles or pregnancy, many studies have adopted either retrospective observational or controlled cohort study designs instead of a double-blinded randomized controlled trial. Even drugs often utilized for controlled ovarian hyperstimulation rarely have been validated its efficacy by double-blinded randomized trials. Over 600 drugs have been

\section{REFERENCES}

1. Mosmann TR, Cherwinski H, Bond MW, Giedlin MA, Coffman RL. Two types of murine helper T cell clone. I. Definition according to profiles of lymphokine activities and secreted proteins. J Immunol. (1986) 136:2348-57.

2. Wegmann TG, Lin H, Guilbert L, Mosmann TR. Bidirectional cytokine interactions in the maternal-fetal relationship: is successful pregnancy a TH2 phenomenon? Immunol Today. (1993) 14:353-6. doi: 10.1016/01675699(93)90235-D

3. Piccinni MP, Beloni L, Livi C, Maggi E, Scarselli G, Romagnani S. Defective production of both leukemia inhibitory factor and type 2 T-helper cytokines by decidual $\mathrm{T}$ cells in unexplained recurrent abortions. Nat Med. (1998) 4:1020-4. doi: 10.1038/2006

4. Raghupathy R. Thl-type immunity is incompatible with successful pregnancy. Immunol Today. (1997) 18:478-82. doi: 10.1016/S0167-5699(97) 01127-4

5. Saito S, Sakai M. Th1/Th2 balance in preeclampsia. J Reproduct Immunol. (2003) 59:161-73. doi: 10.1016/S0165-0378(03)00045-7 approved by the US Food and Drug Administration between 1980 to 2010 , and $91 \%$ of them have been meagerly investigated for the safety of pregnant women (181). Hence, doubleblinded randomized trials for pregnancy outcome or conception trials for new drugs seem a remote possibility in the near future. Until we figure out this dilemma, more data are needed under the stringent guidelines for the investigation and development of therapeutic approaches in women with $\mathrm{T}$ cell abnormalities.

\section{CONCLUSION}

During pregnancy, a complex network of Th cells and their subsets participates in immune responses at the maternal-fetal interface. Th1, Th2, Th9, Th17, Th22, and Tfh immunities have been documented at the maternal-fetal junction but, perhaps more specific and distinctive Th subsets may present. Constraints of paternal alloantigen expression on the trophoblast cells may represent one of many mechanisms to control Th cell activation. Others may include hormonal regulations and the expression of checkpoint molecules on various immune effectors and trophoblasts, such as PD-1/PD-L1 and TIM3/Gal9. Failures to maintain adequate Th1/Th2 and Th17/Treg cell balance are associated with RPL, RIF, and 2nd and 3rdtrimester complications. A few promising therapeutic options are available to regulate $\mathrm{Th}$ cell activation at the maternalfetal junction. Further investigation of therapeutic options to control Th cell activation may shed light on treating various diseases, including cancerous disease, autoimmune diseases, and obstetrical complications.

\section{AUTHOR CONTRIBUTIONS}

WW and JK-K wrote the first draft of the manuscript. NS drew the figures. AG-S and JK-K reviewed and edited the manuscript. All authors contributed to the article and approved the submitted version.

6. Chaouat G, Ledee-Bataille N, Zourbas S, Ostojic S, Dubanchet S, Martal J, et al. Cytokines, implantation and early abortion: re-examining the Th1/Th2 paradigm leads to question the single pathway, single therapy concept. Am J Reproduct Immunol. (2003) 50:177-86. doi: 10.1034/j.1600-0897.2003. 00080.x

7. Bates MD, Quenby S, Takakuwa K, Johnson PM, Vince GS. Aberrant cytokine production by peripheral blood mononuclear cells in recurrent pregnancy loss? Hum Reprod. (2002) 17:2439-44. doi: 10.1093/humrep/17.9.2439

8. Chaouat G, Voisin GA. Regulatory T cell subpopulations in pregnancy. I. Evidence for suppressive activity of the early phase of MLR. J Immunol. (1979) 122:1383-8.

9. Saito S, Nakashima A, Shima T, Ito M. Th1/Th2/Th17 and regulatory T-cell paradigm in pregnancy. Am J Reproduct Immunol. (2010) 63:601-10. doi: 10.1111/j.1600-0897.2010.00852.x

10. Jiang TT, Chaturvedi V, Ertelt JM, Kinder JM, Clark DR, Valent AM, et al. Regulatory $\mathrm{T}$ cells: new keys for further unlocking the enigma of fetal tolerance and pregnancy complications. J Immunol. (2014) 192:4949-56. doi: 10.4049/jimmunol.1400498 
11. Wang WJ, Hao CF, Yi L, Yin GJ, Bao SH, Qiu LH, et al. Increased prevalence of T helper 17 (Th17) cells in peripheral blood and decidua in unexplained recurrent spontaneous abortion patients. J Reproduct Immunol. (2010) 84:164-70. doi: 10.1016/j.jri.2009.12.003

12. Azevedo RSS, De Sousa JR, Araujo MTF, Martins Filho AJ, De Alcantara BN, Araujo FMC, et al. In situ immune response and mechanisms of cell damage in central nervous system of fatal cases microcephaly by Zika virus. Sci Rep. (2018) 8:1. doi: 10.1038/s41598-017-17765-5

13. Piccinni MP, Lombardelli L, Logiodice F, Kullolli O, Parronchi P, Romagnani S. How pregnancy can affect autoimmune diseases progression? Clin Mol Allergy. (2016) 14:11. doi: 10.1186/s12948-016-0048-x

14. Logiodice F, Lombardelli L, Kullolli O, Haller H, Maggi E, Rukavina D, et al. Decidual Interleukin-22-Producing CD4+ T Cells (Th17/Th0/IL-22+ and Th17/Th2/IL-22+, Th2/IL-22+, Th0/IL-22+), Which Also Produce IL4, Are Involved in the Success of Pregnancy. Int J Mol Sci. (2019) 20:428. doi: 10.3390/ijms20020428

15. Monteiro C, Kasahara TM, Castro JR, Sacramento PM, Hygino J, Centurião $\mathrm{N}$, et al. Pregnancy favors the expansion of circulating functional follicular helper T Cells. J Reproduct Immunol. (2017) 121:1-10. doi: 10.1016/j.jri.2017. 04.007

16. Tilburgs T, Meissner TB, Ferreira LMR, Mulder A, Musunuru K, Ye J, et al. NLRP2 is a suppressor of NF-kB signaling and HLA-C expression in human trophoblastsdagger,double dagger. Biol Reproduct. (2017) 96:831-42. doi: 10.1093/biolre/iox009

17. Billingham RE, Brent L, Medawar PB. 'Actively acquired tolerance' of foreign cells. 1953. J Immunol. (2010) 184:5-8. doi: 10.4049/jimmunol.0990109

18. Tersigni C, Redman CW, Dragovic R, Tannetta D, Scambia G, Di Simone $\mathrm{N}$, et al. HLA-DR is aberrantly expressed at feto-maternal interface in preeclampsia. J Reproduct Immunol. (2018) 129:48-52. doi: 10.1016/j.jri.2018. 06.024

19. Tilburgs T, Scherjon SA, Claas FH. Major histocompatibility complex (MHC)-mediated immune regulation of decidual leukocytes at the fetalmaternal interface. J Reproduct Immunol. (2010) 85:58-62. doi: 10.1016/j. jri.2010.01.005

20. Tilburgs T, Scherjon SA, van der Mast BJ, Haasnoot GW, Versteeg VDV-MM, Roelen DL, et al. Fetal-maternal HLA-C mismatch is associated with decidual $\mathrm{T}$ cell activation and induction of functional T regulatory cells. $J$ Reproduct Immunol. (2009) 82:148-57. doi: 10.1016/j.jri.2009.05.003

21. Erlebacher A. Immunology of the maternal-fetal interface. Ann Rev Immunol. (2013) 31:387-411. doi: 10.1146/annurev-immunol-032712-100003

22. Erlebacher A, Vencato D, Price KA, Zhang D, Glimcher LH. Constraints in antigen presentation severely restrict $\mathrm{T}$ cell recognition of the allogeneic fetus. J Clin Investigat. (2007) 117:1399-411. doi: 10.1172/JCI28214

23. Papuchova H, Meissner TB, Li Q, Strominger JL, Tilburgs T. The dual role of HLA-C in tolerance and immunity at the maternal-fetal interface. Front Immunol. (2019) 10:2730. doi: 10.3389/fimmu.2019.02730

24. Mor G, Aldo P, Alvero AB. The unique immunological and microbial aspects of pregnancy. Nat Rev Immunol. (2017) 17:469-82. doi: 10.1038/nri.2017.64

25. Krey G, Frank P, Shaikly V, Barrientos G, Cordo-Russo R, Ringel F, et al. In vivo dendritic cell depletion reduces breeding efficiency, affecting implantation and early placental development in mice. J Mol Med (Berl). (2008) 86:999-1011. doi: 10.1007/s00109-008-0379-2

26. Germain SJ, Sacks GP, Sooranna SR, Sargent IL, Redman CW. Systemic inflammatory priming in normal pregnancy and preeclampsia: the role of circulating syncytiotrophoblast microparticles. J Immunol. (2007) 178:594956. doi: 10.4049/jimmunol.178.9.5949

27. Sargent IL, Borzychowski AM, Redman CW. NK cells and human pregnancy-an inflammatory view. Trends Immunol. (2006) 27:399-404. doi: 10.1016/j.it.2006.06.009

28. Gupta AK, Rusterholz C, Holzgreve W, Hahn S. Syncytiotrophoblast microparticles do not induce apoptosis in peripheral $\mathrm{T}$ lymphocytes, but differ in their activity depending on the mode of preparation. J Reproduct Immunol. (2005) 68:15-26. doi: 10.1016/j.jri.2005.05.003

29. Knieke K, Lingel H, Chamaon K, Brunner-Weinzierl MC. Migration of Th1 lymphocytes is regulated by CD152 (CTLA-4)-mediated signaling via PI3 kinase-dependent Akt activation. PLoS One. (2012) 7:e31391. doi: 10.1371/ journal.pone.0031391
30. Huang X, Cai Y, Ding M, Zheng B, Sun H, Zhou J. Human chorionic gonadotropin promotes recruitment of regulatory $\mathrm{T}$ cells in endometrium by inducing chemokine CCL2. J Reproduct Immunol. (2020) 137:102856. doi: 10.1016/j.jri.2019.102856

31. Tilburgs T, Roelen DL, van der Mast BJ, de Groot-Swings GM, Kleijburg C, Scherjon SA, et al. Evidence for a selective migration of fetus-specific CD4+CD25bright regulatory $\mathrm{T}$ cells from the peripheral blood to the decidua in human pregnancy. J Immunol. (2008) 180:5737-45. doi: 10.4049/ jimmunol.180.8.5737

32. Saito S, Shiozaki A, Sasaki Y, Nakashima A, Shima T, Ito M. Regulatory T cells and regulatory natural killer (NK) cells play important roles in fetomaternal tolerance. Semin Immunopathol. (2007) 29:115-22. doi: 10.1007/ s00281-007-0067-2

33. Saito S. Cytokine network at the feto-maternal interface. J Reproduct Immunol. (2000) 47:87-103. doi: 10.1016/S0165-0378(00)00060-7

34. Torchinsky A, Shepshelovich J, Orenstein H, Zaslavsky Z, Savion S, Carp $\mathrm{H}$, et al. TNF-alpha protects embryos exposed to developmental toxicants. Am J Reproduct Immunol. (2003) 49:159-68. doi: 10.1034/j.1600-0897.2003. 01174.x

35. Todt JC, Yang Y, Lei J, Lauria MR, Sorokin Y, Cotton DB, et al. Effects of tumor necrosis factor-alpha on human trophoblast cell adhesion and motility. Am J Reproduct Immunol. (1996) 36:65-71. doi: 10.1111/j.16000897.1996.tb00141.x

36. Bauer S, Pollheimer J, Hartmann J, Husslein P, Aplin JD, Knofler M. Tumor necrosis factor-alpha inhibits trophoblast migration through elevation of plasminogen activator inhibitor-1 in first-trimester villous explant cultures. J Clin Endocrinol Metabol. (2004) 89:812-22. doi: 10.1210/jc.2003-031351

37. Renaud SJ, Postovit LM, Macdonald-Goodfellow SK, McDonald GT, Caldwell JD, Graham CH. Activated macrophages inhibit human cytotrophoblast invasiveness in vitro. Biol Reproduct. (2005) 73:237-43. doi: 10.1095/ biolreprod.104.038000

38. Seki H, Matuoka K, Inooku H, Takeda S. TNF-alpha from monocyte of patients with pre-eclampsia-induced apoptosis in human trophoblast cell line. J Obstetr Gynaecol Res. (2007) 33:408-16. doi: 10.1111/j.1447-0756. 2007.00551.x

39. Hung TH, Charnock-Jones DS, Skepper JN, Burton GJ. Secretion of tumor necrosis factor-alpha from human placental tissues induced by hypoxiareoxygenation causes endothelial cell activation in vitro: a potential mediator of the inflammatory response in preeclampsia. Am J Pathol. (2004) 164:104961. doi: 10.1016/S0002-9440(10)63192-6

40. Chen Q, Stone PR, McCowan LM, Chamley LW. Activated endothelial cells resist displacement by trophoblast in vitro. Placenta. (2007) 28:743-7. doi: 10.1016/j.placenta.2006.10.004

41. Meisser A, Chardonnens D, Campana A, Bischof P. Effects of tumour necrosis factor-alpha, interleukin-1 alpha, macrophage colony stimulating factor and transforming growth factor beta on trophoblastic matrix metalloproteinases. Mol Hum Reproduct. (1999) 5:252-60. doi: 10.1093/ molehr/5.3.252

42. Lockwood CJ, Oner C, Uz YH, Kayisli UA, Huang SJ, Buchwalder LF, et al. Matrix metalloproteinase 9 (MMP9) expression in preeclamptic decidua and MMP9 induction by tumor necrosis factor alpha and interleukin 1 beta in human first trimester decidual cells. Biol Reproduct. (2008) 78:1064-72. doi: 10.1095/biolreprod.107.063743

43. Jokhi PP, King A, Sharkey AM, Smith SK, Loke YW. Screening for cytokine messenger ribonucleic acids in purified human decidual lymphocyte populations by the reverse-transcriptase polymerase chain reaction. $J$ Immunol. (1994) 153:4427-35.

44. Delassus S, Coutinho GC, Saucier C, Darche S, Kourilsky P. Differential cytokine expression in maternal blood and placenta during murine gestation. J Immunol. (1994) 152:2411-20.

45. Ashkar AA, Di Santo JP, Croy BA. Interferon gamma contributes to initiation of uterine vascular modification, decidual integrity, and uterine natural killer cell maturation during normal murine pregnancy. J Exp Med. (2000) 192:259-70. doi: 10.1084/jem.192.2.259

46. Miyazaki S, Tsuda H, Sakai M, Hori S, Sasaki Y, Futatani T, et al. Predominance of Th2-promoting dendritic cells in early human pregnancy decidua. J Leukoc Biol. (2003) 74:514-22. doi: 10.1189/jlb.1102566 
47. Ashkar AA, Croy BA. Interferon-gamma contributes to the normalcy of murine pregnancy. Biol Reproduct. (1999) 61:493-502. doi: 10.1095/ biolreprod61.2.493

48. Raphael I, Nalawade S, Eagar TN, Forsthuber TG. T cell subsets and their signature cytokines in autoimmune and inflammatory diseases. Cytokine. (2015) 74:5-17. doi: 10.1016/j.cyto.2014.09.011

49. Tayade C, Fang Y, Hilchie D, Croy BA. Lymphocyte contributions to altered endometrial angiogenesis during early and midgestation fetal loss. J Leukoc Biol. (2007) 82:877-86. doi: 10.1189/jlb.0507330

50. Murphy SP, Tayade C, Ashkar AA, Hatta K, Zhang J, Croy BA. Interferon gamma in successful pregnancies. Biol Reproduct. (2009) 80:848-59. doi: 10.1095/biolreprod.108.073353

51. Renaud SJ, Cotechini T, Quirt JS, Macdonald-Goodfellow SK, Othman M, Graham CH. Spontaneous pregnancy loss mediated by abnormal maternal inflammation in rats is linked to deficient uteroplacental perfusion. $J$ Immunol. (2011) 186:1799-808. doi: 10.4049/jimmunol.1002679

52. Lin Y, Ren L, Wang W, Di J, Zeng S, Saito S. Effect of TLR3 and TLR7 activation in uterine NK cells from non-obese diabetic (n.d.) mice. $J$ Reproduct Immunol. (2009) 82:12-23. doi: 10.1016/j.jri.2009.03.004

53. Ebina Y, Shimada S, Deguchi M, Maesawa Y, Iijima N, Yamada H. Divergence of helper, cytotoxic, and regulatory $\mathrm{T}$ cells in the decidua from miscarriage. Am J Reproduct Immunol. (2016) 76:199-204. doi: 10.1111/aji.12546

54. Jin LP, Fan DX, Zhang T, Guo PF, Li DJ. The costimulatory signal upregulation is associated with Th1 bias at the maternal-fetal interface in human miscarriage. Am J Reproduct Immunol. (2011) 66:270-8. doi: 10. 1111/j.1600-0897.2011.00997.x

55. Makhseed M, Raghupathy R, Azizieh F, Omu A, Al-Shamali E, Ashkanani L. Th1 and Th2 cytokine profiles in recurrent aborters with successful pregnancy and with subsequent abortions. Hum Reprod. (2001) 16:2219-26. doi: 10.1093/humrep/16.10.2219

56. Kwak-Kim JY, Chung-Bang HS, Ng SC, Ntrivalas EI, Mangubat CP, Beaman $\mathrm{KD}$, et al. Increased $\mathrm{T}$ helper 1 cytokine responses by circulating $\mathrm{T}$ cells are present in women with recurrent pregnancy losses and in infertile women with multiple implantation failures after IVF. Hum Reprod. (2003) 18:767-73. doi: 10.1093/humrep/deg156

57. Ng SC, Gilman-Sachs A, Thaker P, Beaman KD, Beer AE, Kwak-Kim J. Expression of intracellular Th1 and Th2 cytokines in women with recurrent spontaneous abortion, implantation failures after IVF/ET or normal pregnancy. Am J Reproduct Immunol. (2002) 48:77-86. doi: 10.1034/ j.1600-0897.2002.01105.x

58. Ahmadi M, Abdolmohammadi-Vahid S, Ghaebi M, Aghebati-Maleki L, Afkham A, Danaii S, et al. Effect of Intravenous immunoglobulin on Th1 and Th2 lymphocytes and improvement of pregnancy outcome in recurrent pregnancy loss (RPL). Biomed Pharmacother Biomed Pharmacother. (2017) 92:1095-102. doi: 10.1016/j.biopha.2017.06.001

59. Muyayalo KP, Li ZH, Mor G, Liao AH. Modulatory effect of intravenous immunoglobulin on Th17/Treg cell balance in women with unexplained recurrent spontaneous abortion. Am J Reproduct Immunol. (2018) 80:e13018. doi: 10.1111/aji.13018

60. Nakagawa K, Kwak-Kim J, Kuroda K, Sugiyama R, Yamaguchi K. Immunosuppressive treatment using tacrolimus promotes pregnancy outcome in infertile women with repeated implantation failures. Am J Reproduct Immunol. (2017) 78:e12682. doi: 10.1111/aji. 12682

61. Fu J, Li L, Qi L, Zhao L. A randomized controlled trial of etanercept in the treatment of refractory recurrent spontaneous abortion with innate immune disorders. Taiwan J Obstetr Gynecol. (2019) 58:621-5. doi: 10.1016/j.tjog. 2019.07.007

62. Winger EE, Reed JL. Original article: treatment with tumor necrosis factor inhibitors and intravenous immunoglobulin improves live birth rates in women with recurrent spontaneous abortion. Am J Reproduct Immunol. (2008) 60:8-16. doi: 10.1111/j.1600-0897.2008.00585.x

63. Kim NY, Cho HJ, Kim HY, Yang KM, Ahn HK, Thornton S, et al. Thyroid autoimmunity and its association with cellular and humoral immunity in women with reproductive failures. Am J Reproduct Immunol. (2011) 65:7887. doi: 10.1111/j.1600-0897.2010.00911.x

64. Guimarães PM, Scavuzzi BM, Stadtlober NP, Santos LFDRF, Lozovoy MAB, Iriyoda TMV, et al. Cytokines in systemic lupus erythematosus: far beyond
Th1/Th2 dualism lupus: cytokine profiles. Immunol Cell Biol. (2017) 95:82431. doi: $10.1038 / \mathrm{icb} .2017 .53$

65. Xiao J, Zhu F, Liu X, Xiong J. Th1/Th2/Th17/Treg expression in cultured PBMCs with antiphospholipid antibodies. Mol Med Rep. (2012) 6:1035-9. doi: 10.3892/mmr.2012.1055

66. Psianou K, Panagoulias I, Papanastasiou AD, de Lastic A-L, Rodi M, Spantidea PI, et al. Clinical and immunological parameters of Sjögren's syndrome. Autoimmun Rev. (2018) 17:1053-64. doi: 10.1016/j.autrev.2018. 05.005

67. Peña-Romero AG, García-Romero MT. Diagnosis and management of linear scleroderma in children. Curr Opin Pediatr. (2019) 31:482-90. doi: 10.1097/ MOP.0000000000000785

68. Cellini M, Santaguida MG, Stramazzo I, Capriello S, Brusca N, Antonelli A, et al. Recurrent pregnancy loss in women with hashimoto's thyroiditis with concurrent non-endocrine autoimmune disorders. Thyroid. (2020) 30:45762. doi: $10.1089 /$ thy.2019.0456

69. Kemp M, Thomas W. Antiphospholipid syndrome in obstetrics. Lupus. (2018) 27:28-31. doi: 10.1177/0961203318801664

70. Kwak-Kim J, Agcaoili MS, Aleta L, Liao A, Ota K, Dambaeva S, et al. Management of women with recurrent pregnancy losses and antiphospholipid antibody syndrome. Am J Reproduct Immunol. (2013) 69:596-607. doi: 10.1111/aji.12114

71. Kwak-Kim J, Lee SK, Gilman-Sachs A. Elevated Th1/Th2 cell ratios in a pregnant woman with a history of RSA, secondary Sjogren's syndrome and rheumatoid arthritis complicated with one fetal demise of twin pregnancy. Am J Reproduct Immunol. (2007) 58:325-9. doi: 10.1111/j.1600-0897.2007. 00506.x

72. Yi HJ, Kim JH, Koo HS, Bae JY, Cha SW, Yang KM. Elevated natural killer cell levels and autoimmunity synergistically decrease uterine blood flow during early pregnancy. Obstet Gynecol Sci. (2014) 57:208-15. doi: 10.5468/ogs.2014. 57.3.208

73. Lin H, Mosmann TR, Guilbert L, Tuntipopipat S, Wegmann TG. Synthesis of T helper 2-type cytokines at the maternal-fetal interface. J Immunol. (1993) 151:4562-73.

74. Daher S, de Arruda KGD, Blotta MH, Mamoni RL, Reck AP, Camano L, et al. Cytokines in recurrent pregnancy loss. J Reproduct Immunol. (2004) 62:151-7. doi: 10.1016/j.jri.2003.10.004

75. Fallon PG, Jolin HE, Smith P, Emson CL, Townsend MJ, Fallon R, et al. IL-4 induces characteristic Th2 responses even in the combined absence of IL5, IL-9, and IL-13. Immunity. (2002) 17:7-17. doi: 10.1016/S1074-7613(02) 00332-1

76. Piccinni MP, Scaletti C, Vultaggio A, Maggi E, Romagnani S. Defective production of LIF, M-CSF and Th2-type cytokines by T cells at fetomaternal interface is associated with pregnancy loss. J Reproduct Immunol. (2001) 52:35-43. doi: 10.1016/S0165-0378(01)00111-5

77. Piccinni MP, Lombardelli L, Logiodice F, Kullolli O, Romagnani S, Le Bouteiller P. T helper cell mediated-tolerance towards fetal allograft in successful pregnancy. Clin Mol Allergy. (2015) 13:9. doi: 10.1186/s12948015-0015-y

78. Michimata T, Tsuda H, Sakai M, Fujimura M, Nagata K, Nakamura M, et al. Accumulation of CRTH2-positive T-helper 2 and T-cytotoxic 2 cells at implantation sites of human decidua in a prostaglandin $\mathrm{D}(2)$-mediated manner. Mol Hum Reproduct. (2002) 8:181-7. doi: 10.1093/molehr/8.2.181

79. Tsuda H, Michimata T, Sakai M, Nagata K, Nakamura M, Saito S. A novel surface molecule of Th2- and Tc2-type cells, CRTH2 expression on human peripheral and decidual CD4+ and CD8+ T cells during the early stage of pregnancy. Clin Exp Immunol. (2001) 123:105-11. doi: 10.1046/j.1365-2249. 2001.01422.x

80. Matthiesen L, Kalkunte S, Sharma S. Multiple pregnancy failures: an immunological paradigm. Am J Reproduct Immunol. (2012) 67:334-40. doi: 10.1111/j.1600-0897.2012.01121.x

81. Mitchell RE, Hassan M, Burton BR, Britton G, Hill EV, Verhagen J, et al. IL-4 enhances IL-10 production in Th1 cells: implications for Th1 and Th2 regulation. Sci Rep. (2017) 7:11315. doi: 10.1038/s41598-017-11803-y

82. Swain SL, Weinberg AD, English M, Huston G. IL-4 directs the development of Th2-like helper effectors. J Immunol. (1990) 145:3796-806.

83. Holtan SG, Chen Y, Kaimal R, Creedon DJ, Enninga EA, Nevala WK, et al. Growth modeling of the maternal cytokine milieu throughout 
normal pregnancy: macrophage-derived chemokine decreases as inflammation/counterregulation increases. J Immunol Res. (2015) 2015:952571. doi: 10.1155/2015/952571

84. Illera VA, Perandones CE, Stunz LL, Mower DA Jr., Ashman RF. Apoptosis in splenic B lymphocytes. Regulation by protein kinase C and IL-4. J Immunol. (1993) 151:2965-73.

85. Jara LJ, Medina G, Cruz-Dominguez P, Navarro C, Vera-Lastra O, Saavedra MA. Risk factors of systemic lupus erythematosus flares during pregnancy. Immunol Res. (2014) 60:184-92. doi: 10.1007/s12026-014-8577-1

86. Breitfeld D, Ohl L, Kremmer E, Ellwart J, Sallusto F, Lipp M, et al. Follicular $\mathrm{B}$ helper T cells express CXC chemokine receptor 5, localize to B cell follicles, and support immunoglobulin production. J Exp Med. (2000) 192:1545-52. doi: $10.1084 /$ jem.192.11.1545

87. Schaerli P, Willimann K, Lang AB, Lipp M, Loetscher P, Moser B. CXC chemokine receptor 5 expression defines follicular homing $\mathrm{T}$ cells with $\mathrm{B}$ cell helper function. J Exp Med. (2000) 192:1553-62. doi: 10.1084/jem.192.11. 1553

88. Zeng W, Liu Z, Zhang S, Ren J, Ma X, Qin C, et al. Characterization of T follicular helper cells in allogeneic normal pregnancy and PDL1 blockageinduced abortion. Sci Rep. (2016) 6:36560-36560. doi: 10.1038/srep36560

89. Kaplan MH. Th9 cells: differentiation and disease. Immunol Rev. (2013) 252:104-15. doi: 10.1111/imr.12028

90. Micossé CL, von Meyenn OS, Kipfer E, Adam C, Simillion C, Jafari SMS, et al. Human "T(H)9" cells are a subpopulation of PPAR- $\gamma(+) \mathrm{T}(\mathrm{H}) 2$ cells. $S c i$ Immunol. (2019) 4:eaat5943. doi: 10.1126/sciimmunol.aat5943

91. Veldhoen M, Uyttenhove C, van Snick J, Helmby H, Westendorf A, Buer J, et al. Transforming growth factor-beta 'reprograms' the differentiation of $\mathrm{T}$ helper 2 cells and promotes an interleukin 9-producing subset. Nat Immunol. (2008) 9:1341-6. doi: 10.1038/ni.1659

92. Putheti P, Awasthi A, Popoola J, Gao W, Strom TB. Human CD4+ memory T cells can become CD4+IL-9+ T cells. PLoS One. (2010) 5:e8706. doi: 10.1371/journal.pone.0008706

93. Demoulin JB, Renauld JC. Interleukin 9 and its receptor: an overview of structure and function. Int Rev Immunol. (1998) 16:345-64. doi: 10.3109/ 08830189809043001

94. Wilhelm C, Hirota K, Stieglitz B, Van Snick J, Tolaini M, Lahl K, et al. An IL-9 fate reporter demonstrates the induction of an innate IL-9 response in lung inflammation. Nat Immunol. (2011) 12:1071-7. doi: 10.1038/ni.2133

95. Nowak EC, Weaver CT, Turner H, Begum-Haque S, Becher B, Schreiner B, et al. IL-9 as a mediator of Th17-driven inflammatory disease. J Exp Med. (2009) 206:1653-60. doi: 10.1084/jem.20090246

96. Habbeddine M, Verbeke P, Karaz S, Bobé P, Kanellopoulos-Langevin C. Leukocyte population dynamics and detection of IL-9 as a major cytokine at the mouse fetal-maternal interface. PLoS One. (2014) 9:e107267. doi: 10.1371/journal.pone.0107267

97. Gomez-Lopez N, Olson DM, Robertson SA. Interleukin-6 controls uterine Th9 cells and CD8(+) T regulatory cells to accelerate parturition in mice. Immunol Cell Biol. (2016) 94:79-89. doi: 10.1038/icb.2015.63

98. Croy BA, Chantakru S, Esadeg S, Ashkar AA, Wei Q. Decidual natural killer cells: key regulators of placental development (a review). J Reproduct Immunol. (2002) 57:151-68. doi: 10.1016/S0165-0378(02)00005-0

99. Nakashima A, Ito M, Yoneda S, Shiozaki A, Hidaka T, Saito S. Circulating and decidual Th17 cell levels in healthy pregnancy. Am J Reproduct Immunol. (2010) 63:104-9. doi: 10.1111/j.1600-0897.2009.00771.x

100. Santner-Nanan B, Peek MJ, Khanam R, Richarts L, Zhu E, Fazekas B, et al. Systemic increase in the ratio between Foxp3+ and IL-17-producing CD4+ $\mathrm{T}$ cells in healthy pregnancy but not in preeclampsia. J Immunol. (2009) 183:7023-30. doi: 10.4049/jimmunol.0901154

101. Cua DJ, Tato CM. Innate IL-17-producing cells: the sentinels of the immune system. Nat Rev Immunol. (2010) 10:479-89. doi: 10.1038/nri2800

102. Pongcharoen S, Supalap K. Interleukin-17 increased progesterone secretion by JEG-3 human choriocarcinoma cells. Am J Reproduct Immunol. (2009) 61:261-4. doi: 10.1111/j.1600-0897.2009.00693.x

103. Travis OK, White D, Pierce WA, Ge Y, Stubbs CY, Spradley FT, et al. Chronic infusion of interleukin-17 promotes hypertension, activation of cytolytic natural killer cells, and vascular dysfunction in pregnant rats. Physiol Rep. (2019) 7:e14038. doi: 10.14814/phy2.14038
104. Peck A, Mellins ED. Breaking old paradigms: Th17 cells in autoimmune arthritis. Clin Immunol. (2009) 132:295-304. doi: 10.1016/j.clim.2009.03.522

105. Crome SQ, Wang AY, Levings MK. Translational mini-review series on Th17 cells: function and regulation of human Thelper 17 cells in health and disease. Clin Exp Immunol. (2010) 159:109-19. doi: 10.1111/j.1365-2249.2009. 04037.x

106. Nakashima A, Ito M, Shima T, Bac ND, Hidaka T, Saito S. Accumulation of IL-17-positive cells in decidua of inevitable abortion cases. Am J Reproduct Immunol. (2010) 64:4-11. doi: 10.1111/j.1600-0897.2010.00812.x

107. Lee SK, Kim JY, Hur SE, Kim CJ, Na BJ, Lee M, et al. An imbalance in interleukin-17-producing $\mathrm{T}$ and Foxp3(+) regulatory $\mathrm{T}$ cells in women with idiopathic recurrent pregnancy loss. Hum Reprod. (2011) 26:2964-71. doi: 10.1093/humrep/der301

108. Lee SK, Kim JY, Lee M, Gilman-Sachs A, Kwak-Kim J. Th17 and regulatory $\mathrm{T}$ cells in women with recurrent pregnancy loss. Am J Reproduct Immunol. (2012) 67:311-8. doi: 10.1111/j.1600-0897.2012.01116.x

109. Wilczynski JR. Immunological analogy between allograft rejection, recurrent abortion and pre-eclampsia-the same basic mechanism? Hum Immunol. (2006) 67:492-511. doi: 10.1016/j.humimm.2006.04.007

110. Liu YS, Wu L, Tong XH, Wu LM, He GP, Zhou GX, et al. Study on the relationship between Th17 cells and unexplained recurrent spontaneous abortion. Am J Reproduct Immunol. (2011) 65:503-11. doi: 10.1111/j.16000897.2010.00921.x

111. Wu L, Li J, Xu HL, Xu B, Tong XH, Kwak-Kim J, et al. IL-7/IL-7R signaling pathway might play a role in recurrent pregnancy losses by increasing inflammatory Th17 cells and decreasing Treg cells. Am J Reproduct Immunol. (2016) 76:454-64. doi: 10.1111/aji.12588

112. Sereshki N, Gharagozloo M, Ostadi V, Ghahiri A, Roghaei MA, Mehrabian F, et al. Variations in T-helper 17 and regulatory T cells during the menstrual cycle in peripheral blood of women with recurrent spontaneous abortion. Int J Fertil Steril. (2014) 8:59-66.

113. Jia L, Wu C. The biology and functions of Th22 cells. Adv Exp Med Biol. (2014) 841:209-30. doi: 10.1007/978-94-017-9487-9_8

114. Wang Y, Xu B, Li MQ, Li DJ, Jin LP. IL-22 secreted by decidual stromal cells and NK cells promotes the survival of human trophoblasts. Int J Clin Exp Pathol. (2013) 6:1781-90.

115. Graham AC, Carr KD, Sieve AN, Indramohan M, Break TJ, Berg RE. IL-22 production is regulated by IL-23 during Listeria monocytogenes infection but is not required for bacterial clearance or tissue protection. PLoS One. (2011) 6:e17171. doi: 10.1371/journal.pone.0017171

116. Dambaeva S, Schneiderman S, Jaiswal MK, Agrawal V, Katara GK, GilmanSachs A, et al. Interleukin 22 prevents lipopolysaccharide- induced preterm labor in mice. Biol Reproduct. (2018) 98:299-308. doi: 10.1093/biolre/iox182

117. Plank MW, Kaiko GE, Maltby S, Weaver J, Tay HL, Shen W, et al. Th22 Cells form a distinct $\mathrm{Th}$ lineage from Th17 cells in vitro with unique transcriptional properties and tbet-dependent Th1 plasticity. J Immunol. (2017) 198:218290. doi: 10.4049/jimmunol.1601480

118. Roomandeh N, Saremi A, Arasteh J, Pak F, Mirmohammadkhani M, Kokhaei $\mathrm{P}$, et al. Comparing serum levels of Th17 and treg cytokines in women with unexplained recurrent spontaneous abortion and fertile women. Iran J Immunol. (2018) 15:59-67.

119. O'Hern Perfetto C, Fan X, Dahl S, Krieg S, Westphal LM, Bunker Lathi R, et al. Expression of interleukin-22 in decidua of patients with early pregnancy and unexplained recurrent pregnancy loss. J Assist Reprod Genet. (2015) 32:977-84. doi: 10.1007/s10815-015-0481-7

120. Lu KT, Kanno Y, Cannons JL, Handon R, Bible P, Elkahloun AG, et al. Functional and epigenetic studies reveal multistep differentiation and plasticity of in vitro-generated and in vivo-derived follicular $\mathrm{T}$ helper cells. Immunity. (2011) 35:622-32. doi: 10.1016/j.immuni.2011. 07.015

121. Freeman GJ, Long AJ, Iwai Y, Bourque K, Chernova T, Nishimura H, et al. Engagement of the PD-1 immunoinhibitory receptor by a novel B7 family member leads to negative regulation of lymphocyte activation. J Exp Med. (2000) 192:1027-34. doi: 10.1084/jem.192.7.1027

122. Agata Y, Kawasaki A, Nishimura H, Ishida Y, Tsubata T, Yagita H, et al. Expression of the PD-1 antigen on the surface of stimulated mouse $\mathrm{T}$ and B lymphocytes. Int Immunol. (1996) 8:765-72. doi: 10.1093/intimm/8.5.765 
123. Petroff MG, Chen L, Phillips TA, Azzola D, Sedlmayr P, Hunt JS. B7 family molecules are favorably positioned at the human maternal-fetal interface. Biol Reprod. (2003) 68:1496-504. doi: 10.1095/biolreprod.102.010058

124. Guleria I, Khosroshahi A, Ansari MJ, Habicht A, Azuma M, Yagita H, et al. A critical role for the programmed death ligand 1 in fetomaternal tolerance. J Exp Med. (2005) 202:231-7. doi: 10.1084/jem.20050019

125. Carter L, Fouser LA, Jussif J, Fitz L, Deng B, Wood CR, et al. PD-1:PD-L inhibitory pathway affects both $\mathrm{CD} 4(+)$ and CD8(+) T cells and is overcome by IL-2. Eur J Immunol. (2002) 32:634-43. doi: 10.1002/1521-4141(200203) 32:3<634::AID-IMMU634>3.0.CO;2-9

126. Zhang YH, Tian M, Tang MX, Liu ZZ, Liao AH. Recent insight into the role of the PD-1/PD-L1 pathway in feto-maternal tolerance and pregnancy. Am J Reprod Immunol. (2015) 74:201-8. doi: 10.1111/aji.12365

127. Fife BT, Guleria I, Bupp MG, Eagar TN, Tang Q, Bour-Jordan H, et al. Insulin-induced remission in new-onset NOD mice is maintained by the PD-1-PD-L1 pathway. J Exp Med. (2006) 203:2737-47. doi: 10.1084/jem. 20061577

128. Francisco LM, Sage PT, Sharpe AH. The PD-1 pathway in tolerance and autoimmunity. Immunol Rev. (2010) 236:219-42. doi: 10.1111/j.1600-065X. 2010.00923.x

129. Asano T, Meguri Y, Yoshioka T, Kishi Y, Iwamoto M, Nakamura M, et al. PD-1 modulates regulatory T-cell homeostasis during low-dose interleukin-2 therapy. Blood. (2017) 129:2186-97. doi: 10.1182/blood-2016-09-741629

130. Wafula PO, Teles A, Schumacher A, Pohl K, Yagita H, Volk HD, et al. PD1 but not CTLA-4 blockage abrogates the protective effect of regulatory T cells in a pregnancy murine model. Am J Reprod Immunol. (2009) 62:283-92. doi: 10.1111/j.1600-0897.2009.00737.x

131. Habicht A, Dada S, Jurewicz M, Fife BT, Yagita H, Azuma M, et al. A link between PDL1 and T regulatory cells in fetomaternal tolerance. J Immunol. (2007) 179:5211-9. doi: 10.4049/jimmunol.179.8.5211

132. Sugita S, Kawazoe Y, Imai A, Usui Y, Takahashi M, Mochizuki M. Suppression of IL-22-producing T helper 22 cells by RPE cells via PD-L1/PD1 interactions. Invest Ophthalmol Vis Sci. (2013) 54:6926-33. doi: 10.1167/ iovs.13-12703

133. Wang C, Lu Y, Chen L, Gao T, Yang Q, Zhu C, et al. Th9 cells are subjected to PD-1/PD-L1-mediated inhibition and are capable of promoting CD8 T cell expansion through IL-9R in colorectal cancer. Int Immunopharmacol. (2019) 78:106019. doi: 10.1016/j.intimp.2019.106019

134. Wang WJ, Garcia MDS, Deutsch G, Sung N, Yang X, He Q, et al. PD-1 and PD-L1 expression on T-cell subsets in women with unexplained recurrent pregnancy losses. Am J Reproduct Immunol. (2020) 83:e13230. doi: 10.1111/ aji. 13230

135. Zhu C, Anderson AC, Schubart A, Xiong H, Imitola J, Khoury SJ, et al. The Tim-3 ligand galectin-9 negatively regulates T helper type 1 immunity. Nat Immunol. (2005) 6:1245-52. doi: 10.1038/ni1271

136. Miyanishi N, Nishi N, Abe H, Kashio Y, Shinonaga R, Nakakita S, et al. Carbohydrate-recognition domains of galectin- 9 are involved in intermolecular interaction with galectin-9 itself and other members of the galectin family. Glycobiology. (2007) 17:423-32. doi: 10.1093/glycob/cwm001

137. Seki M, Oomizu S, Sakata KM, Sakata A, Arikawa T, Watanabe K, et al. Galectin-9 suppresses the generation of Th17, promotes the induction of regulatory $\mathrm{T}$ cells, and regulates experimental autoimmune arthritis. Clin Immunol. (2008) 127:78-88. doi: 10.1016/j.clim.2008.01.006

138. Oomizu S, Arikawa T, Niki T, Kadowaki T, Ueno M, Nishi N, et al. Cell surface galectin-9 expressing Th cells regulate Th17 and Foxp3+ Treg development by galectin-9 secretion. PLoS One. (2012) 7:e48574. doi: 10.1371/journal. pone. 0048574

139. Zhao J, Lin B, Deng H, Zhi X, Li Y, Liu Y, et al. Decreased expression of TIM-3 on Th17 cells associated with ophthalmopathy in patients with graves' disease. Curr Mol Med. (2018) 18:83-90. doi: 10.2174/ 1566524018666180705105753

140. Talukdar A, Sharma KA, Rai R, Deka D, Rao DN. Effect of coenzyme Q10 on Th1/Th2 paradigm in females with idiopathic recurrent pregnancy loss. Am J Reproduct Immunol. (2015) 74:169-80. doi: 10.1111/aji.12376

141. Wang S, Cao C, Piao H, Li Y, Tao Y, Zhang X, et al. Tim-3 protects decidual stromal cells from toll-like receptor-mediated apoptosis and inflammatory reactions and promotes Th2 bias at the maternal-fetal interface. Sci Rep. (2015) 5:9013. doi: 10.1038/srep09013
142. Wu M, Zhu Y, Zhao J, Ai H, Gong Q, Zhang J, et al. Soluble costimulatory molecule sTim 3 regulates the differentiation of Th1 and Th2 in patients with unexplained recurrent spontaneous abortion. Int J Clin Exp Med. (2015) 8:8812-9.

143. Zhuang X, Xia X, Liu L, Zhang Y, Zhang X, Wang C. Expression of Tim-3 in peripheral blood mononuclear cells and placental tissue in unexplained recurrent spontaneous abortion. Medicine (Baltimore). (2018) 97:e12099. doi: 10.1097/MD.0000000000012099

144. Li J, Li FF, Zuo W, Zhou Y, Hao HY, Dang J, et al. Up-regulated expression of Tim-3/Gal-9 at maternal-fetal interface in pregnant woman with recurrent spontaneous abortion. J Huazhong Univ Sci Technolog Med Sci. (2014) 34:586-90. doi: 10.1007/s11596-014-1320-2

145. Li F, Dang J, Jiang M, He M, Yang M, Li J, et al. Upregulation of Tim3 expression at feto-maternal interface may explain embryo survival in the CBAxDBA/2 model of abortion. Am J Reproduct Immunol. (2018) 79:e12775. doi: 10.1111/aji.12775

146. Wang S, Li M, Sun F, Chen C, Ye J, Li D, et al. Altered frequency and function of spleen CTLA-4+Tim-3+ T cells are associated with miscarriage. Biol Reproduct. (2019) 19:ioz076. doi: 10.1093/biolre/ioz076

147. Hu XH, Tang MX, Mor G, Liao AH. Tim-3: Expression on immune cells and roles at the maternal-fetal interface. J Reprod Immunol. (2016) 118:92-9. doi: 10.1016/j.jri.2016.10.113

148. Li Y, Zhang J, Zhang D, Hong X, Tao Y, Wang S, et al. Tim-3 signaling in peripheral NK cells promotes maternal-fetal immune tolerance and alleviates pregnancy loss. Sci Signal. (2017) 10:eaah4323. doi: 10.1126/scisignal. aah4323

149. Wang S, Zhu X, Xu Y, Zhang D, Li Y, Tao Y, et al. Programmed cell death-1 (PD-1) and T-cell immunoglobulin mucin-3 (Tim-3) regulate CD4+ T cells to induce Type 2 helper T cell (Th2) bias at the maternal-fetal interface. Hum Reprod. (2016) 31:700-11. doi: 10.1093/humrep/dew019

150. Kao LC, Tulac S, Lobo S, Imani B, Yang JP, Germeyer A, et al. Global gene profiling in human endometrium during the window of implantation. Endocrinology. (2002) 143:2119-38. doi: 10.1210/endo.143.6.8885

151. Dambaeva S, Beaman K. Role of immunoregulatory cytokine IL-15 in the endometrium. In: Kwak-Kim J editor. Endometrial Gene Expression. Cham: Springer (2020). p. 66-74. doi: 10.1007/978-3-030-28584-5_4

152. Robertson SA, Care AS, Moldenhauer LM. Regulatory T cells in embryo implantation and the immune response to pregnancy. J Clin Investigat. (2018) 128:4224-35. doi: 10.1172/JCI122182

153. Wu L, Liao A, Gilman-Sachs A, Kwak-Kim J. T cell-related endometrial gene expression in normal and complicated pregnancies. In: Kwak-Kim J editor. Endometrial Gene Expression: An Emerging Paradigm for Reproductive Disorders. Cham: Springer International Publishing (2020). p. 51-66. doi: 10.1007/978-3-030-28584-5_3

154. Mekinian A, Cohen J, Alijotas-Reig J, Carbillon L, Nicaise-Roland P, Kayem $\mathrm{G}$, et al. Unexplained recurrent miscarriage and recurrent implantation failure: is there a place for immunomodulation? Am J Reproduct Immunol. (2016) 76:8-28. doi: 10.1111/aji.12493

155. Wang WJ, Hao CF, Qu QL, Wang X, Qiu LH, Lin QD. The deregulation of regulatory $\mathrm{T}$ cells on interleukin-17-producing $\mathrm{T}$ helper cells in patients with unexplained early recurrent miscarriage. Hum Reprod. (2010) 25:2591-6. doi: 10.1093/humrep/deq198

156. Piccinni MP, Scaletti C, Maggi E, Romagnani S. Role of hormone-controlled Th1- and Th2-type cytokines in successful pregnancy. J Neuroimmunol. (2000) 109:30-3. doi: 10.1016/S0165-5728(00)00299-X

157. Piccinni MP, Giudizi MG, Biagiotti R, Beloni L, Giannarini L, Sampognaro S, et al. Progesterone favors the development of human Thelper cells producing Th2-type cytokines and promotes both IL- 4 production and membrane CD30 expression in established Th1 cell clones. J Immunol. (1995) 155:12833.

158. Petitbarat M, Serazin V, Dubanchet S, Wayner R, de Mazancourt P, Chaouat G, et al. Tumor necrosis factor-like weak inducer of apoptosis (TWEAK)/fibroblast growth factor inducible-14 might regulate the effects of interleukin 18 and 15 in the human endometrium. Fertil Steril. (2010) 94:1141-3. doi: 10.1016/j.fertnstert.2009.10.049

159. Fuertes MB, Molinero LL, Toscano MA, Ilarregui JM, Rubinstein N, Fainboim L, et al. Regulated expression of galectin-1 during T-cell activation involves Lck and Fyn kinases and signaling through MEK1/ERK, p38 MAP 
kinase and p70S6 kinase. Mol Cell Biochem. (2004) 267:177-85. doi: 10.1023/ B:MCBI.0000049376.50242.7f

160. He M, Jiang M, Zhou Y, Li F, Yang M, Fan Y, et al. Impaired Gal9 dysregulates the PBMC-induced Th1/Th2 imbalance in abortion-prone matings. J Immunol Res. (2018) 2018:9517842. doi: 10.1155/2018/9517842

161. Lombardelli L, Logiodice F, Aguerre-Girr M, Kullolli O, Haller H, Casart Y, et al. Interleukin-17-producing decidual CD4+ T cells are not deleterious for human pregnancy when they also produce interleukin-4. Clin Mol Allergy. (2016) 14:1. doi: 10.1186/s12948-016-0039-y

162. Raghupathy R. Pregnancy: success and failure within the Th1/Th2/Th3 paradigm. Semin Immunol. (2001) 13:219-27. doi: 10.1006/smim.2001.0316

163. Mor G, Cardenas I, Abrahams V, Guller S. Inflammation and pregnancy: the role of the immune system at the implantation site. Ann N Y Acad Sci. (2011) 1221:80-7. doi: 10.1111/j.1749-6632.2010.05938.x

164. Ali SB, Jeelall Y, Pennell CE, Hart R, McLean-Tooke A, Lucas M. The role of immunological testing and intervention in reproductive medicine: a fertile collaboration? Am J Reproduct Immunol. (2018) 79:e12784. doi: 10.1111/aji. 12784

165. Lee YK, Turner H, Maynard CL, Oliver JR, Chen D, Elson CO, et al. Late developmental plasticity in the T helper 17 lineage. Immunity. (2009) 30:92-107. doi: 10.1016/j.immuni.2008.11.005

166. Cosmi L, Maggi L, Santarlasci V, Capone M, Cardilicchia E, Frosali F, et al. Identification of a novel subset of human circulating memory CD4(+) T cells that produce both IL-17A and IL-4. J Allergy Clin Immunol. (2010) 125:222-30. doi: 10.1016/j.jaci.2009.10.012

167. Annunziato F, Cosmi L, Santarlasci V, Maggi L, Liotta F, Mazzinghi B, et al. Phenotypic and functional features of human Th17 cells. J Exp Med. (2007) 204:1849-61. doi: 10.1084/jem.20070663

168. Lee SK, Na BJ, Kim JY, Hur SE, Lee M, Gilman-Sachs A, et al. Determination of clinical cellular immune markers in women with recurrent pregnancy loss. Am J Reproduct Immunol. (2013) 70:398-411. doi: 10.1111/aji.12137

169. Salek Farrokhi A, Zarnani AH, Moazzeni SM. Mesenchymal stem cells therapy protects fetuses from resorption and induces Th2 type cytokines profile in abortion prone mouse model. Transpl Immunol. (2018) 47:26-31. doi: 10.1016/j.trim.2018.01.002

170. Carpentier PA, Dingman AL, Palmer TD. Placental TNF- $\alpha$ signaling in illness-induced complications of pregnancy. Am J Pathol. (2011) 178:280210. doi: 10.1016/j.ajpath.2011.02.042

171. Albaghdadi AJH, Kan FWK. Immunosuppression with tacrolimus improved implantation and rescued expression of uterine progesterone receptor and its co-regulators FKBP52 and PIASy at nidation in the obese and diabetic mice: Comparative studies with metformin. Mol Cell Endocrinol. (2018) 460:73-84. doi: 10.1016/j.mce.2017.07.007

172. Ota K, Dambaeva S, Han AR, Beaman K, Gilman-Sachs A, Kwak-Kim J. Vitamin D deficiency may be a risk factor for recurrent pregnancy losses by increasing cellular immunity and autoimmunity. Hum Reprod. (2014) 29:208-19. doi: 10.1093/humrep/det424

173. Ota K, Dambaeva S, Kim MW-I, Han A-R, Fukui A, Gilman-Sachs A, et al. 1,25-Dihydroxy-vitamin D3 regulates NK-cell cytotoxicity, cytokine secretion, and degranulation in women with recurrent pregnancy losses. Eur J Immunol. (2015) 45:3188-99. doi: 10.1002/eji.201545541

174. Wang SW, Zhong SY, Lou LJ, Hu ZF, Sun HY, Zhu HY. The effect of intravenous immunoglobulin passive immunotherapy on unexplained recurrent spontaneous abortion: a meta-analysis. Reprod Biomed Online. (2016) 33:720-36. doi: 10.1016/j.rbmo.2016.08.025

175. Ji J, Zhai H, Zhou H, Song S, Mor G, Liao A. The role and mechanism of vitamin D-mediated regulation of Treg/Th17 balance in recurrent pregnancy loss. Am J Reproduct Immunol. (2019) 81:e13112. doi: 10.1111/aji.13112

176. Ghasemnejad-berenji H, Ghaffari Novin M, Hajshafiha M, Nazarian $\mathrm{H}$, Hashemi SM, Ilkhanizadeh $\mathrm{B}$, et al. Immunomodulatory effects of hydroxychloroquine on Th1/Th2 balance in women with repeated implantation failure. Biomed Pharmacother. (2018) 107:1277-85. doi: 10. 1016/j.biopha.2018.08.027

177. Ponticelli C, Moroni G. Fetal toxicity of immunosuppressive drugs in pregnancy. J Clin Med. (2018) 7:552. doi: 10.3390/jcm7120552

178. Kwak-Kim J, Ota K, Sung N, Huang C, Alsubki L, Lee S, et al. COVID-19 and immunomodulation treatment for women with reproductive failures. J Reproduct Immunol. (2020) 141:103168. doi: 10.1016/j.jri.2020.10 3168

179. Timilshina M, Kang Y, Dahal I, You Z, Nam TG, Kim KJ, et al. BJ-3105, a 6-alkoxypyridin-3-ol analog, impairs $\mathrm{T}$ cell differentiation and prevents experimental autoimmune encephalomyelitis disease progression. PLoS One. (2017) 12:e0168942. doi: 10.1371/journal.pone.0168942

180. Ahmad SF, Ansari MA, Nadeem A, Zoheir KMA, Bakheet SA, Alsaad AMS, et al. STA-21, a STAT-3 inhibitor, attenuates the development and progression of inflammation in collagen antibody-induced arthritis. Immunobiology. (2017) 222:206-17. doi: 10.1016/j.imbio.2016.10.001

181. Anthes E. Hard Labour: The Case for Testing Drugs on Pregnant Women. Oakville, ON: Mosaic Press (2015).

Conflict of Interest: The authors declare that the research was conducted in the absence of any commercial or financial relationships that could be construed as a potential conflict of interest.

Copyright $\odot 2020$ Wang, Sung, Gilman-Sachs and Kwak-Kim. This is an open-access article distributed under the terms of the Creative Commons Attribution License (CC BY). The use, distribution or reproduction in other forums is permitted, provided the original author(s) and the copyright owner(s) are credited and that the original publication in this journal is cited, in accordance with accepted academic practice. No use, distribution or reproduction is permitted which does not comply with these terms. 